\title{
PROBABILISTIC SAFETY ASSESSMENT OF OPERATIONAL ACCIDENTS AT THE WASTE ISOLATION PILOT PLANT
}

\section{RECEIVED \\ OCT 102080 \\ OSTI}

Dale F. Rucker

Environmental Evaluation Group

7007 Wyoming Blvd. NE, Suite F-2

Albuquerque, NM 87109

and

505 North Main Street, P.O. Box 3149

Carlsbad, NM 88221-3149

http://www.rt66.com/ eeg

September 2000 


\section{DISCLAIMER}

This report was prepared as an account of work sponsored by an agency of the United States Government. Neither the United States Government nor any agency thereof, nor any of their employees, make any warranty, express or implied, or assumes any legal liability or responsibility for the accuracy, completeness, or usefulness of any information, apparatus, product, or process disclosed, or represents that its use would not infringe privately owned rights. Reference herein to any specific commercial product, process, or service by trade name, trademark, manufacturer, or otherwise does not necessarily constitute or imply its endorsement, recommendation, or favoring by the United States Government or any agency thereof. The views and opinions of authors expressed herein do not necessarily state or reflect those of the United States Government or any agency thereof. 


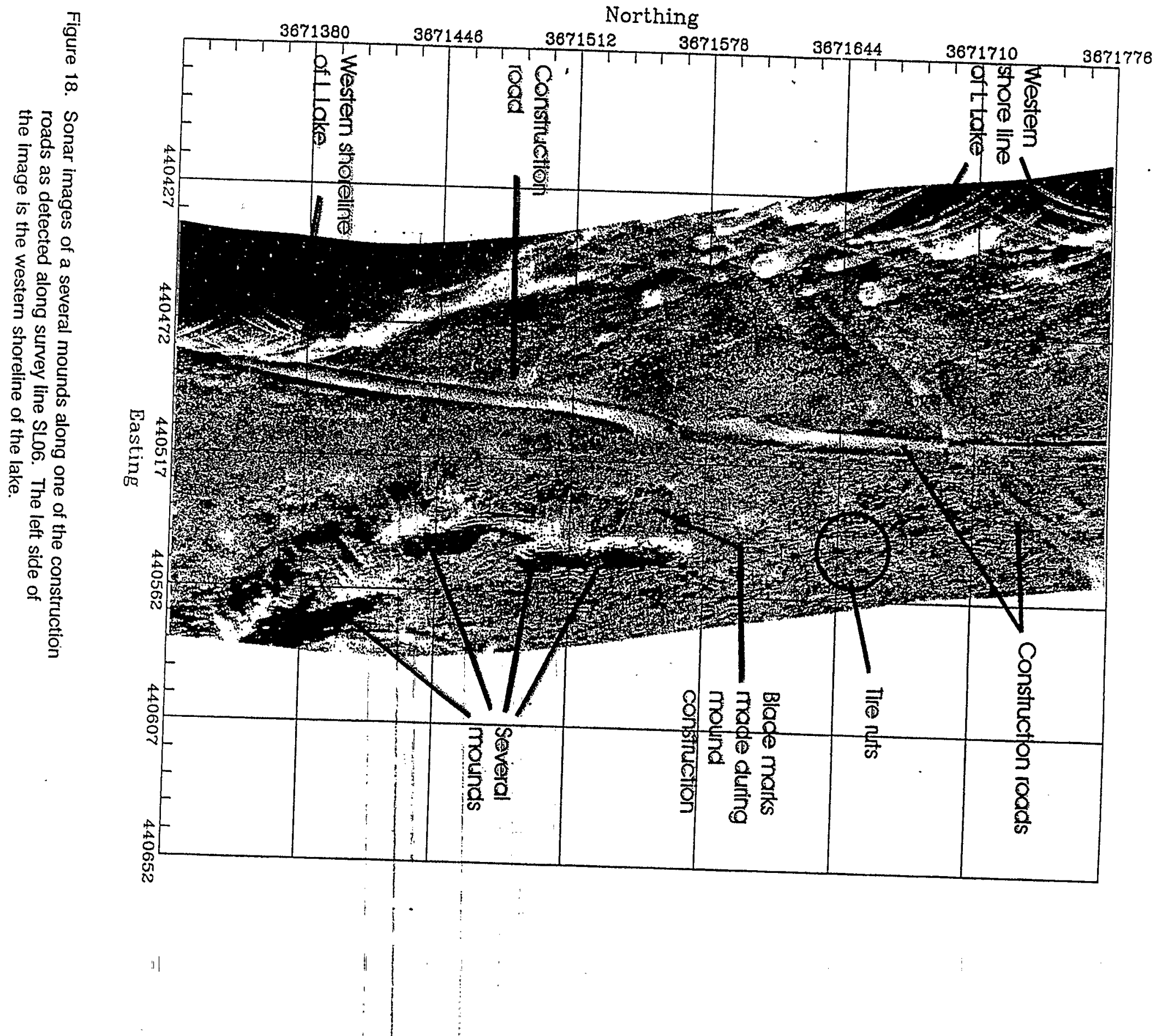




\section{FOREWORD}

The purpose of the New Mexico Environmental Evaluation Group (EEG) is to conduct an independent technical evaluation of the Waste Isolation Pilot Plant (WIPP) Project to ensure the protection of the public health and safety and the environment. The WIPP Project, located in southeastern New Mexico, became operational in March 1999 for the disposal of transuranic (TRU) radioactive wastes generated by the national defense programs. The EEG was established in 1978 with funds provided by the U. S. Department of Energy (DOE) to the State of New Mexico. Public Law 100-456, the National Defense Authorization Act, Fiscal Year 1989, Section 1433, assigned EEG to the New Mexico Institute of Mining and Technology and continued the original contract DE-AC04-79AL10752 through DOE contract DE-ACO489AL58309. The National Defense Authorization Act for Fiscal Year 1994, Public Law 103160, and the National Defense Authorization Act for Fiscal Year 2000, Public Law 106-65, continued the authorization.

EEG performs independent technical analyses of the suitability of the proposed site; the design of the repository, its operation, and its long-term integrity; suitability and safety of the transportation systems; suitability of the Waste Acceptance Criteria and the compliance of the generator sites with them; and related subjects. These analyses include assessments of reports issued by the DOE and its contractors, other federal agencies and organizations, as they relate to the potential health, safety and environmental impacts from WIPP. Another important function of EEG is the independent environmental monitoring of radioactivity in air, water, and soil, both on-site and off-site.

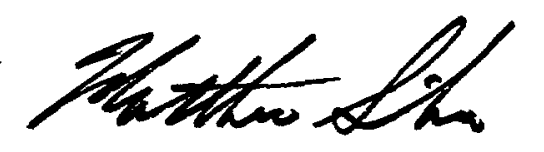

Matthew K. Silva

Director 


\section{EEG STAFF}

Sally C. Ballard, B.S., Radiochemical Analyst

William T. Bartlett, Ph.D., Health Physicist

Radene Bradley, Secretary III

James K. Channell, Ph.D., CHP, Environmental Engineer/Health Physicist

Lokesh Chaturvedi, Ph.D., Deputy Director \& Engineering Geologist

Patricia D. Fairchild, Secretary III

Donald H. Gray, M.A., Laboratory Manager

Linda Kennedy, M.L.S, Technical Editor/Librarian

Jim W. Kenney, M.S., Environmental Scientist/Supervisor

Lanny King, Assistant Environmental Technician

Dale F. Rucker, M.S., Environmental Engineer

Jill Shortencarier, Executive Assistant

Matthew K. Silva, Ph.D., Director

Susan Stokum, Administrative Secretary

Ben A. Walker, B.A., Quality Assurance Specialist

Brenda J. West, B.A., Administrative Officer 


\section{ACKNOWLEDGEMENTS}

I acknowledge the contributions by Matthew Silva, Ben Walker, Jim Channell, and Bill Bartlett for their excellent comments and diligent review. I also want to thank Linda Kennedy for fixing my references and Jill Shortencarrier for her work in getting this report published. 


\section{TABLE OF CONTENTS}

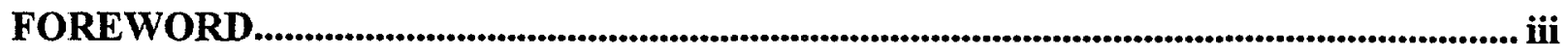

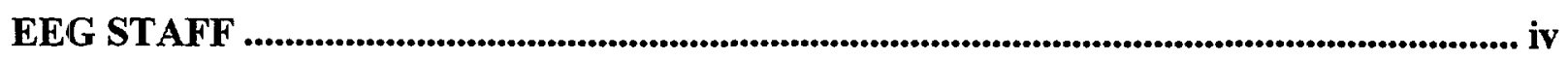

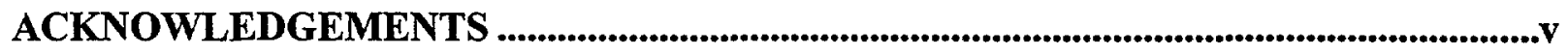

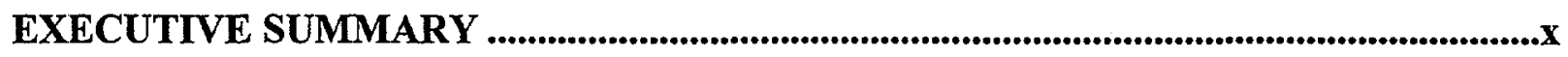

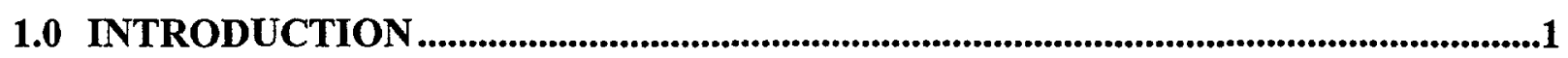

1.1 Probabilistic Safety Assessment....................................................................2

1.2 Normal Operational Procedures .............................................................................

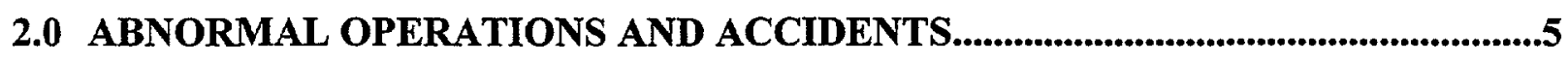

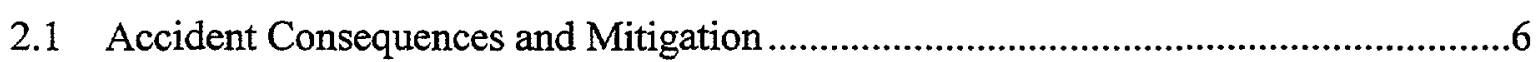

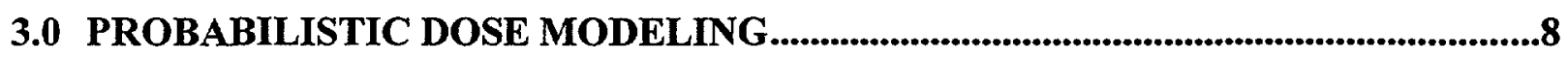

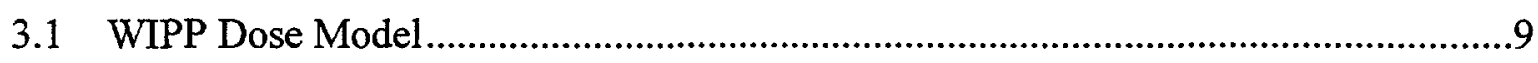

3.2 Site-Specific Meteorological Conditions ...............................................................10

3.3 General Description of Meteorological Conditions at WIPP ................................14

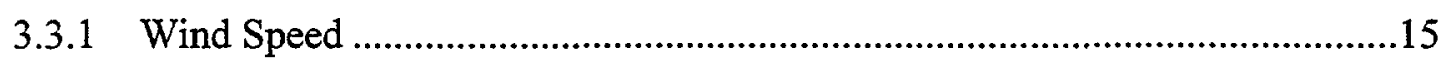

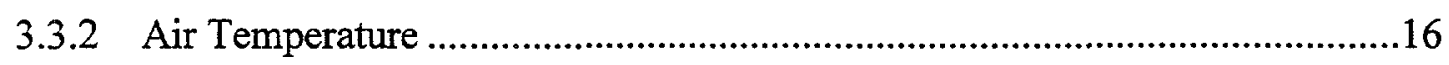

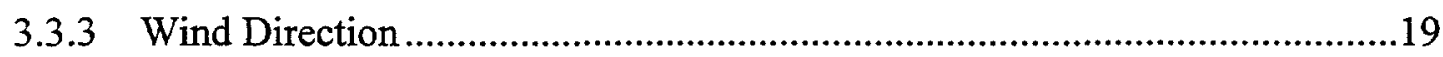

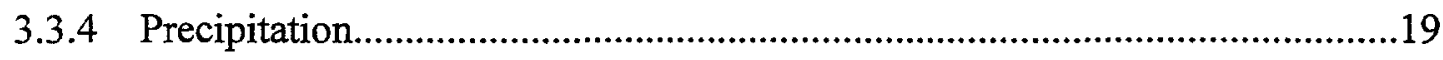

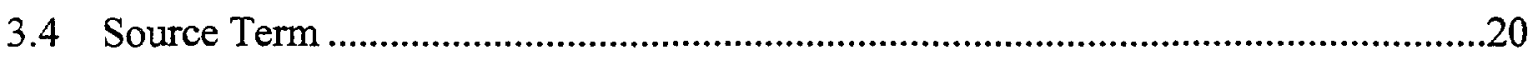

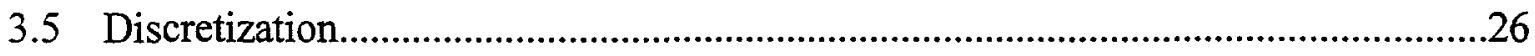


6.0 REFERENCES

7.0 ACRONYMS .36

LIST OF EEG REPORTS 37 


\section{LIST OF TABLES}

Table I. Listing of Accident Scenarios in the WIPP Safety Analysis Report .........................5

Table II. Dose Calculations for an Above Ground Worker from Each Accident Scenario from the SAR, Appendix E.............................................................................7

Table III. Fitting Coefficients for Dispersion Factors (Hey 1994) .....................................12

Table IV. Classification of Atmospheric Stability (U.S. NRC 1972) .................................17

Table V. WIPP Stability Class Designation for September 1996 to May 1999 by

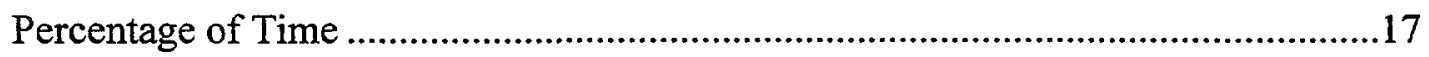

Table VI. Example DR, ARF, and RFs used in Formulating the Source Term .....................22

Table VII. Weighted Fraction Used in Formulating the Source Term ....................................26

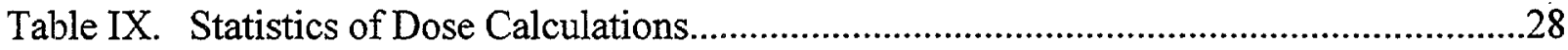




\section{LIST OF FIGURES}

Figure 1. Location of WIPP Meteorological Towers........................................................10

Figure 2. Gaussian Plume Dispersion Model12

Figure 3. Maximum and Average (over an entire month) Wind Speed at WIPP for the Period of September 1996 to May 1999

Figure 4. Monthly Minimum, Average, and Maximum Air Temperature at WIPP for the Period of September 1996 to May 1999 .16

Figure 5. Wind Speed Distribution Separated by Stability Classes

Figure 6. Percentage of Wind Direction (from Direction Indicated) for Meteorological Data from September 1996 to May 1999

Figure 7. Daily Precipitation Record (in Inches) at WIPP from September 1996 to May 1999

Figure 8. Conceptual Model for Source Term Development

Figure 9. PDFs of the Various Generator Sites. .23

Figure 10. Inhalation Dose Distributions for Selected Scenarios. .28

Figure 11. Probabilistic Dose vs. Distance for the Eight Accident Scenarios with 5\%, $50 \%$, and $95 \%$ Confidence Limits 


\section{EXECUTIVE SUMMARY}

This report presents a probabilistic safety assessment of radioactive doses as consequences from accident scenarios to complement the deterministic assessment presented in the Waste Isolation Pilot Plant (WIPP) Safety Analysis Report (SAR). The International Council of Radiation Protection (ICRP) recommends both assessments be conducted to ensure that "an adequate level of safety has been achieved and that no major contributors to risk are overlooked" (ICRP 1993). To that end, the probabilistic assessment for the WIPP accident scenarios addresses the wide range of assumptions, e.g. the range of values representing the radioactive source of an accident, that could possibly have been overlooked by the SAR.

Routine releases of radionuclides from the WIPP repository to the environment during the waste emplacement operations are expected to be essentially zero. In contrast, potential accidental releases from postulated accident scenarios during waste handling and emplacement could be substantial, which necessitates the need for radiological air monitoring and confinement barriers (DOE 1999). The WIPP Safety Analysis Report (SAR) calculated doses from accidental releases to the on-site (at $100 \mathrm{~m}$ from the source) and off-site (at the Exclusive Use Boundary and Site Boundary) public by a deterministic approach. This approach, as demonstrated in the SAR, uses single-point values of key parameters to assess the 50-year, whole-body committed effective dose equivalent (CEDE).

The basic assumptions used in the SAR to formulate the CEDE are retained for this report's probabilistic assessment. However, for the probabilistic assessment, single-point parameter values were replaced with probability density functions (PDF) and were sampled over an expected range. Monte Carlo simulations were run, in which 10,000 iterations were performed by randomly selecting one value for each parameter and calculating the dose. Statistical information was then derived from the 10,000 iteration batch, which included $5 \%, 50 \%$, and $95 \%$ dose likelihood, and the sensitivity of each assumption to the calculated doses.

As one would intuitively expect, the doses from the probabilistic assessment for most scenarios were found to be much less than the deterministic assessment. The lower dose of the 
probabilistic assessment can be attributed to a "smearing" of values from the high and low end of the PDF spectrum of the various input parameters.

The analysis also found a potential weakness in the deterministic analysis used in the SAR; a detail on drum loading was not taken into consideration. Waste emplacement operations thus far have handled drums from each shipment as a single unit, i.e. drums from each shipment are kept together. Shipments typically come from a single waste stream, and therefore the curie loading of each drum can be considered nearly identical to that of its neighbor. Calculations show that if there are large numbers of drums used in the accident scenario assessment, e.g. 28 drums in the waste hoist failure scenario (CH5), then the probabilistic dose assessment calculations will diverge from the deterministically determined doses. As it is currently calculated, the deterministic dose assessment assumes one drum loaded to the maximum allowable ( $80 \mathrm{PE}-\mathrm{Ci}$ ), and the remaining are $10 \%$ of the maximum. The effective average of drum curie content is therefore less in the deterministic assessment than the probabilistic assessment for a large number of drums.

EEG recommends that the WIPP SAR calculations be revisited and updated to include a probabilistic safety assessment. 


\section{PROBABILISTIC SAFETY ASSESSMENT OF OPERATIONAL ACCIDENTS AT THE WASTE ISOLATION PILOT PLANT}

\section{INTRODUCTION}

The Waste Isolation Pilot Plant (WIPP) is a repository, operated by the US Department of Energy (DOE), for disposal of defense transuranic waste. It is located in southeastern New Mexico, approximately 40 kilometers (26 miles) east of Carlsbad in the Delaware Basin. The repository is a mined room and pillar construction $655 \mathrm{~m}$ below the surface in the Salado Formation, which consists mainly of halite (rock salt) with alternating thin layers of anhydrite with clay seams. The WIPP was certified by the US Environmental Protection Agency (EPA) in May 1998 (EPA 1998) as showing compliance with the EPA standards (EPA 1993) and criteria (EPA 1996) for long term disposal. WIPP has been receiving nonmixed transuranic waste (radioactive waste without a significant hazardous waste component) since March 1999.

A RCRA Part B permit was also issued in late November 1999. The permit allows the DOE to dispose of mixed transuranic waste. The hazardous waste constituents of the mixed waste are mainly volatile organic compounds (VOC) in addition to heavy metals, solvents, and asbestos.

As with any nuclear facility, the handling of nuclear materials can pose a risk to onsite workers and to the off-site public. One risk at WIPP involves respirable alpha-emitting radionuclide particles that become airborne as the result of an accident and are subsequently inhaled into the lungs. The consequence from the accident can be assessed by calculating the committed effective dose equivalent (CEDE), which is simply the product of several parameters including breathing rate, source, dose conversion factor, and the site-specific air dispersion factor. A detailed discussion on the calculations is given in Chapter 3.

The probabilistic method used in assessing the expected dose to an individual, described in this report, is not meant to be a predictor of dose (Apostolakis 1978). The purpose of conducting these calculations is to compare with established guidelines to gauge safety. Typically, the assessment will use parameter values that are representative of worst-case or near worst-case 
conditions. For example, the DOE (DOE 1994a) suggests that stable, low wind speed values be used to compute the air dispersion factor. In this respect, the dose can be maximized and give indications of the worst case scenario. However, these types of calculations are inherently conservative, and are not intended to delineate the consequence during actual accidents. One cannot truly know the meteorological conditions for some time in the future, nor what facility operations are being conducted. Thus, one limitation of using probabilistic dose calculations as predictors of consequence is due to the great uncertainty in the values needed to assess dose.

\subsection{Probabilistic Safety Assessment}

Although it is impossible to predict future events, past records can be used to support assumptions about the future behavior of a system. For example, the past several years of meteorological measurements at WIPP indicate that the windspeed will be between $0.134 \mathrm{~m} / \mathrm{s}$ and $16.08 \mathrm{~m} / \mathrm{s}$. These measurements, and the knowledge of how often these windspeeds occur, can be used to assess the consequence for future accidents. Although not a predictor, the method of using a range of windspeeds to capture the uncertainty of measurements can give an indication of more realistic doses. This method is called a probabilistic safety assessment (PSA), and is typically used with the deterministic assessment to "ensure that an adequate level of safety has been achieved and that no major contributors to risk are overlooked" (ICRP 1993).

The use of a PSA to assess inhalation doses at WIPP is the topic of this report. In contrast to a deterministic analysis, where single-point values representing either typical or worst-case site conditions are used, a PSA can capture the entire realm of likely values and quantitatively assess the probability of each outcome. The dose from a windspeed at $2 \mathrm{~m} / \mathrm{s}$, for example, is more likely to occur than a dose from a windspeed at $0.134 \mathrm{~m} / \mathrm{s}$, and would be indicative of onsite meteorological measurements.

The drawback of using a PSA to calculate doses is that there are no guidelines or standards by which to compare consequence. The guidelines of (DOE 1994a) assumes that a deterministically derived dose is less than the given guidance value. A PSA, on the other hand, presents doses on a probability scale, and the choice of probabilistic dose used in comparison with either 
established guidelines or with the deterministic analysis is rather arbitrary. For this probabilistic analysis, a $95 \%$ probability of dose was used to compare with the deterministically determined dose, but was chosen as simply being reasonable and generally accepted among statisticians. A $98 \%$ probability could have easily been used. To that end, the PSA was used to simply compare probabilistic and deterministic doses with one another and to assess the reasonableness of the assumptions used in the deterministic analysis.

A deterministic analysis of possible accident consequences was presented in the WIPP Safety Analysis Report (SAR) (DOE 1999). To successfully compare the doses calculated by the PSA to doses calculated by the deterministic assessment, the same methodology of accident analysis used in the SAR was incorporated into the PSA. For example, the SAR accident assessment of a waste container spontaneously exploding, in which one drum was involved in the accident, was retained for the PSA. The only difference between the analyses is that the PSA used a range of values based on actual measurements of meteorological conditions and drum curie content and sampled from those ranges in a Monte Carlo simulation, where the SAR assumed single-point, worst-case meteorological conditions and an estimated value for drum curie content.

\subsection{Normal Operational Procedures}

The contact-handled $(\mathrm{CH})$ TRU waste will be shipped primarily in 55 gallon drums or steel waste boxes. Much of the waste within the drums and boxes is surrounded by multiple layers of plastic bags intended to mitigate the release of respirable particles during packaging, handling, and storage. Moreover, each drum is fitted with one carbon filter and each box is fitted with two carbon filters designed to allow the release of flammable gas while preventing the release of alpha-emitting particles.

Historically, the WIPP Waste Acceptance Criteria, Revisions 0 through 4, included a specific limit of $1 \%$ by weight of respirable sized particles ( 10 micron) in CH-TRU waste. Moreover, particles less than 200 microns were limited to less than 15\%. Revision 5 of the WAC (DOE 1996) removed the requirement, leaving an unlimited amount of respirable material as acceptable for handling and emplacement in the facility. 
The WIPP Land Withdrawal Act (1996) requires shipment to WIPP in transportation containers certified by the Nuclear Regulatory Commission (NRC). NRC has certified the TRUPACT II, which is a right circular cylinder with a screw top lid. The TRUPACT II provides double containment and is non-vented and it was extensively tested to verify that the package would not be easily breached in a transportation accident. The DOE plans shipment of the TRU-PACT-II by truck, although shipment by rail is still an option.

Upon arrival at WIPP, the waste drums or boxes will be unloaded from the TRUPACT-II in the Waste Handling Building (WHB). The facility is equipped with alpha detecting continuous air monitors and in the event of a release, is also fitted with high efficiency particulate filtration. A description of the ventilation used in the WHB can be found in the WIPP Safety Analysis Report (DOE 1999). The SAR lists the accident scenarios, which could cause an uptake by workers in the WHB, underground, or in and around the above ground facilities.

For final disposal, the waste will be transported down to the mined out panels and emplaced. The mine ventilation system removes the large quantities of dust associated with the mining activity. As a result, during the normal mode of operation, air from the underground is unfiltered and returns to the surface through the exhaust shaft. The air is diverted through HEPA filters only when a release of radionuclides has been detected. Continuous air monitors are intended to provide the information to switch to HEPA filtration. Even if the monitoring system is functioning properly, it may take several minutes before a warning signal to notify the Central Monitoring Room (CMR) would result in the exhaust ventilation being switched to HEPA filtration. In such a case, the uptake of radioactivity by workers on the surface is dictated by the wind speed and stability conditions at the site. 


\section{ABNORMAL OPERATIONS AND ACCIDENTS}

Although waste-handling personnel are trained to safely operate the equipment, hazardous operability studies (Westinghouse 1995) suggest the potential for handling accidents that could breach containers and release radioactive material. Two potential accidents at WIPP include dropping a drum from the waste facility pallet or the waste hoist failing and plummeting a substantial distance to the underground. Such accidents may result in possible worker exposure to radioactive material and that will be the focus of this report. Other accidents involving personal injury or equipment damage that do not release radioactive material will not be investigated here.

The SAR postulates several accident scenarios. Table I lists the possible accidents and the probability associated with each accident as stated in the SAR, Appendix D (DOE 1999). The frequency of occurrence is based on fault tree analysis.

Table I. Listing of Accident Scenarios in the WIPP Safety Analysis Report.

\begin{tabular}{|l|l|l|}
\hline Scenario Description & Scenario Name & Accidents Probability \\
\hline Spontaneous Ignition of Drum in WHB & $\mathrm{CH} 1$ & $1.3 \times 10^{-8} / \mathrm{yr}$ \\
\hline Crane Failure in WHB & $\mathrm{CH} 2^{*}$ & $9.8 \times 10^{-3} / \mathrm{yr}$ \\
\hline Puncture of Waste Container in WHB & $\mathrm{CH} 3$ & $8.0 \times 10^{-3} / \mathrm{yr}$ \\
\hline Waste Container Drop in WHB & $\mathrm{CH} 4$ & $1.5 \times 10^{-2} / \mathrm{yr}$ \\
\hline Waste Hoist Failure & $\mathrm{CH} 5^{* *}$ & $1.9 \times 10^{-9} / \mathrm{yr}$ \\
\hline Seismic Event & $\mathrm{CH} 6$ & N.A. \\
\hline Spontaneous Ignition of Drum Underground & $\mathrm{CH} 7$ & $4.8 \times 10^{-7} / \mathrm{yr}$ \\
\hline Aircraft Crash & $\mathrm{CH} 8$ & N.A. \\
\hline Waste Container Drop Underground & $\mathrm{CH} 9$ & $2 \times 10^{-2}$ \\
\hline Tornado Event & $\mathrm{CH} 10$ & N.A. \\
\hline Underground Roof Fall & $\mathrm{CH} 11$ & $4.7 \times 10^{-7} / \mathrm{yr}$ \\
\hline
\end{tabular}

* EEG-74 (Greenfield and Sargent 2000) demonstrates the uncertainty associated with the expected annual frequency of a crane accident.

** EEG-44 (Greenfield 1990), EEG-59 (Greenfield and Sargent 1995), and EEG-65 (Greenfield and Sargent 1998) demonstrates the uncertainty associated with the expected annual frequency of a waste hoist accident. 


\subsection{Accident Consequences And Mitigation}

The consequence of each accident was calculated in the SAR by estimating the radioactive dose from potential uptake of airborne radioactivity into the body. The worker is subjected to a radioactive plume on the surface, outside of the WHB. The plume is a result of an accident above or underground and is released through the exhaust shaft or WHB ventilation. The dose calculations considered the source of each accident and how much material could be respirable, the breathing rate, and wind speed and plume dispersion at the site. Together, these terms form the committed effective dose equivalent (CEDE), which is calculated by

$\mathrm{CEDE}=\mathrm{D}=\mathrm{Q} * \chi / \mathrm{Q} * \mathrm{BR} * \mathrm{DCF}$

where $\mathrm{D}$ is simply the dose in $\mathrm{rem}^{\mathbf{1}}, \mathrm{Q}$ is the source term in plutonium-equivalent curies (PE$\mathrm{Ci})^{2}, \chi / \mathrm{Q}$ is the site-specific air dispersion factor in $\mathrm{s} / \mathrm{m}^{3}, \mathrm{BR}$ is breathing rate (equal to $20 \mathrm{l} / \mathrm{min}$ as stipulated in IRCP-23 (ICRP 1974)), and DCF is the dose conversion factor for converting the source activity of $\mathrm{Pu}-239$ to rem (assumed $\mathrm{W}^{3}$ class, consistent with the SAR; $5.1 \times 10^{8} \mathrm{rem} / \mathrm{Ci}$ ).

Table II lists the consequence calculations reported in the SAR, Appendix E (DOE 1999) for each of the scenarios listed above. The table also shows the source term assumptions used in formulating the dose, and any effects of mitigation. Mitigation for the aboveground WHB facility includes continuous on-line High Efficiency Particulate (HEPA) filtration of ventilation, and underground mitigation includes switching the underground exhaust flow to HEPA filtration in the case of an accident. HEPA filtration for the underground exhaust cannot be continuously on-line since the additional pressure drop reduces the underground airflow, which falls far below levels allowed by the RCRA Subpart B permit and other MSHA standards for miners working with diesel equipment. For calculations of a mitigated release, the leakpath factor is considered

\footnotetext{
${ }^{1}$ For consistency with the SAR, English units for dose (rem) and activity (Ci) are presented. The SI equivalents are Sieverts (Sv) for dose and Bequerels $(\mathrm{Bq})$ for activity. $100 \mathrm{rem}=1 \mathrm{~Sv} .1 \mathrm{Ci}=3.7 \times 10^{10} \mathrm{~Bq}$.

${ }^{2}$ A.ll quantities of radionuclides in the waste are expressed as $\mathrm{Pu}-239$ equivalent curies (PE-Ci). The PE-Ci is derived by comparing the 50 -year effective whole-body dose commitment due to inhalation of various radionuclides to that of $\mathrm{Pu}-239$.

${ }^{3}$ The $\mathrm{W}$ class is a simple classification for the chemical form of the radionuclide referring to the retention time in the body. $W$ is short for weekly; others include $D$ as in days and $Y$ as in years.
} 
to be $1 \times 10^{-6}$ for an above ground release, i.e., a reduction of dose by $10^{6}$ is expected. No credit for mitigation is taken for a release underground.

Table II. Dose calculations for an above ground worker from each accident scenario from the SAR, Appendix E.

\begin{tabular}{|l|l|l|l|l|}
\hline $\begin{array}{l}\text { Accident } \\
\text { Scenario }\end{array}$ & $\begin{array}{l}\text { Number of Drums } \\
\text { Used in Source } \\
\text { Term }\end{array}$ & $\begin{array}{l}\text { Drum Loading } \\
\text { in PE-Ci }\end{array}$ & $\begin{array}{l}\text { Unmitigated } \\
\text { Dose (rem) at } \\
\mathbf{1 0 0 ~ m}\end{array}$ & $\begin{array}{l}\text { Mitigated Dose } \\
\text { (rem) at 100 m }\end{array}$ \\
\hline $\mathrm{CH} 1$ & 1 & 80 & 33 & $3.3 \times 10^{-5}$ \\
\hline $\mathrm{CH} 2$ & 7 & $1 @ 80,6 @ 8$ & 2.7 & $2.7 \times 10^{-6}$ \\
\hline $\mathrm{CH} 2{ }^{*}$ & 1 (damaged) & 1100 & 0.16 & $1.6 \times 10^{-7}$ \\
\hline $\mathrm{CH} 2^{* *}$ & 7 (damaged) & $7 @ 80$ & 12 & $1.2 \times 10^{-5}$ \\
\hline $\mathrm{CH} 3$ & 4 & $1 @ 80,3 @ 8$ & 3.8 & $3.8 \times 10^{-6}$ \\
\hline $\mathrm{CH} 3^{*}$ & 1 (damaged) & 1100 & 0.15 & $1.5 \times 10^{-7}$ \\
\hline $\mathrm{CH} 3^{* *}$ & 4 (damaged) & $4 @ 80$ & 8 & $8 \times 10^{-6}$ \\
\hline $\mathrm{CH} 4$ & 4 & $1 @ 80,3 @ 8$ & 0.86 & $8.6 \times 10^{-7}$ \\
\hline $\mathrm{CH} 4{ }^{*}$ & 1 (damaged) & 1100 & 0.0091 & $9.1 \times 10^{-9}$ \\
\hline $\mathrm{CH} 4 * *$ & 4 (damaged) & $4 @ 80$ & 2.7 & $2.7 \times 10^{-6}$ \\
\hline $\mathrm{CH} 5$ & 28 & $1 @ 80,27 @ 8$ & 61 & $6.1 \times 10^{-5}$ \\
\hline $\mathrm{CH} 7$ & 1 & 80 & 33 & - \\
\hline $\mathrm{CH} 9$ & 7 & $1 @ 80,6 @ 8$ & 2.7 & - \\
\hline $\mathrm{CH}{ }^{*}$ & 1 (damaged) & 1100 & 0.23 & - \\
\hline $\mathrm{CH}{ }^{* *}$ & 7 (damaged) & $7 @ 80$ & 1.2 & - \\
\hline $\mathrm{CH} 11$ & 21 & $1 @ 80,20 @ 8$ & 5.2 & - \\
\hline
\end{tabular}

* Dose consequences are calculated by estimating the effects of a damaged drum with a loading of 1100 PE-Ci. Drum loading above $80 \mathrm{PE}-\mathrm{Ci}$ are usually placed in a $85-$ gallon drum overpack or reprocessed for safer confinement.

** Dose consequences are calculated by assuming a worst case scenario. Drums above $80 \mathrm{PE}-\mathrm{Ci}$ are usually overpacked or reprocessed and it is postulated that the source from this drum load would represent the largest dose possible.

It should be noted that the curie content of each waste material type that will be shipped in the TRUPACT is limited by the decay heat content limit. This limit is dependent on the waste matrix and the number of plastic bags of containment. About two-thirds of the volume of $\mathrm{CH}$ TRU waste will be limited to a maximum of $1.0-8.0$ curies/drum. Only about one-third of the waste (solid inorganic material in metal cans) is allowed to contain greater than $80 \mathrm{Ci}$. Thus, several 80 PE-Ci drums in an accident scenario is a low probability event. 


\section{PROBABILISTIC DOSE MODELING}

The use of probabilistic modeling has gained much attention in the last several years, especially in the nuclear industry with respect to radiation safety and potential exposure. The International Commission on Radiation Protection (ICRP) identified two complementary techniques to assess the potential exposure to individuals: deterministic and probabilistic assessment methods (ICRP 1993).

The more familiar of the two is the deterministic method, where an outcome is calculated based on ne set of input values. This technique was used in the WIPP SAR, shown above in Table II, where the dose was calculated with one value for the source, breathing rate, dose conversion factor, and site-specific meteorological conditions. In addition, the sensitivity of certain variables was tested to evaluate the outcome to various conditions. For example, the drum loading parameter was changed to assess the doses that could be expected from the different drum curie content. The drum curie content was increased to calculate the effect of a worst case release, if there were an accident. Although the sensitivity of variables in Eq. 1 is rather intuitive, these 'What if' scenarios allow the modeler to bound the range of doses that could be expected.

Probabilistic dose modeling, also known as probabilistic safety analysis (PSA) is very similar to the deterministic modeling; the variables are still linked in the equations by addition or multiplication. However, the PSA addresses the 'What if' scenario automatically by generating a number of scenarios based on the probability of the input variables. Each input variable inherently has uncertainty in the measurement, and it is the goal of the PSA to give weight to a value of each variable by the value's probability of occurrence, which is characterized by a probability distribution.

The technique used here for assessing the probability distribution of each variable is the Monte Carlo simulation. The Monte Carlo simulation randomly selects (or samples) a value from the probability distribution of each variable to produce a multitude of scenarios (or iterations). The

probability distribution is sampled in a manner that best reproduces the shape of the distribution 
(Vose 1996), with the purpose of capturing the uncertainty of each variable. The greater number of iterations chosen, the higher the accuracy of that distribution.

Modeling the dose using Eq. 1 was set up using a Microsoft Excel spreadsheet and an aftermarket plug-in called Crystal Ball (Decisioneering 1998). Crystal Ball allows the user to specify a probability distribution for each input variable and the number of iterations to be performed. The result of modeling Eq. 1 was a forecast of doses including a confidence associated with those doses. Confidence allows one to gauge the accuracy of the results, and is usually displayed as a percentage. If, for example, the dose was calculated to be 3 rem for a set of Monte Carlo simulations with a confidence of $95 \%$, one could be assured that $95 \%$ of the calculated doses fell at or below 3 rem. Described differently, one could be $95 \%$ certain (confident) that the dose would fall at or below 3 rem, assuming the input probability distributions are reasonable.

The precision of the PSA relies heavily on the choice of probability distribution chosen to represent the uncertainty of each variable (Vose 1996). Care must be used in formulating the function that best represents the empirical data in the model. The probability distribution function (PDF) therefore, must be adequately understood if the model results are to have any meaning.

\subsection{WIPP Dose Model}

The WIPP dose model, predicated on Eq. 1, was assigned PDFs for site specific meteorological conditions for the air dispersion factor $(\chi / Q)$ and source term $(Q)$, but left the breathing rate (BR) and dose conversion factor (DCF) as constant values. The breathing rate for a worker under light activity (20 1/m or $3.34 \mathrm{~m}^{3} / \mathrm{s}$ ) was established in ICRP-23 (Hey 1994) and was used in the WIPP SAR. The DCF of $5.1 \times 10^{8} \mathrm{rem} / \mathrm{Pu}-239 \mathrm{Ci}$ (DOE 1988), also from the SAR, was also retained for consistency. 


\subsection{Site-Specific Meteorological Conditions}

In September 1996 DOE established well-sited meteorological towers for measuring atmospheric conditions at WIPP. The meteorological conditions will dictate the speed and direction of a contaminated, aerosolized particulate plume. For a more complete discussion, see Rucker (2000).

WIPP has two meteorological towers: a primary Meteorological Station and the WIPP Far Field (secondary meteorological monitoring station) (Westinghouse 1997). Figure 2.1 shows the proximity of the towers to WIPP boundaries. The primary station is located approximately 500 $\mathrm{m}(1640 \mathrm{ft})$ to the northeast of the exhaust shaft and houses a 50-meter (164-ft) instrument station. The secondary station is located approximately $1000 \mathrm{~m}$ to the northwest of the exhaust shaft and houses a 10-meter (32.8-ft) instrument station.

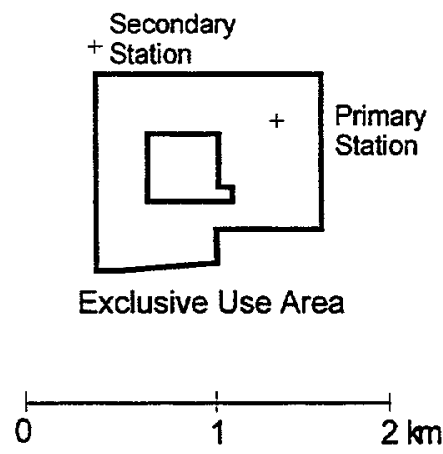

Figure 1. Location of WIPP Meteorological Towers.

The most significant use of WIPP meteorological data, other than establishing ambient conditions, is modeling a plume release from the exhaust shaft during an underground accident and release of aerosolized radioactive particles. The models used in estimating the concentration of a contaminant at a given point typically employ the Gaussian straight-line continuous plume transport equation for air dispersion. The equation assumes the site-specific, relative concentration factor $(\chi / \mathrm{Q})$ in $\left[\mathrm{T} / \mathrm{L}^{3}\right]$, 


$$
\frac{\chi}{Q}=\frac{f(y) g(z)}{2 \pi \sigma_{y} \sigma_{z} u}
$$

where $u$ is the wind speed $[\mathrm{L} / \mathrm{T}], \sigma_{\mathrm{y}}$ is the lateral dispersion factor $[\mathrm{L}], \sigma_{\mathrm{z}}$ is the vertical dispersion factor $[\mathrm{L}]$, and $\mathrm{f}(\mathrm{y})$ and $\mathrm{g}(\mathrm{z})$ are horizontal and vertical correction factors, respectively, and the equation is governed by the wind speed, wind stability class, and stack height exclusively. $f(y)$ and $g(z)$ are represented by

$$
\begin{aligned}
& f(y)=\exp \left[-\frac{1}{2}\left(\frac{y}{\sigma_{y}}\right)^{2}\right] \\
& g(z)=\exp \left[-\frac{1}{2}\left(\frac{h_{e}-z}{\sigma_{z}}\right)^{2}\right]
\end{aligned}
$$

where $h_{e}$ is the effective plume height. The effective plume height is equal to the stack height, $h_{s}$, plus any change in height, $\Delta \mathrm{h}$, due either to plume rise, stack downwash or gravitational settling. Figure 2 shows a graphical model of Gaussian plume dispersion.

The Gaussian nature of the plume spread in either lateral or vertical direction is represented by a dispersion factor, $\sigma$. This dispersion factor accounts for plume spread by mechanical and/or chemical mixing from empirical fitting formulae based on Pasquill-Gifford-Turner curves (Hey 1994). The curves for dispersion factors $\sigma_{\mathrm{y}}$ and $\sigma_{\mathrm{z}}$ are represented by the equations below. 


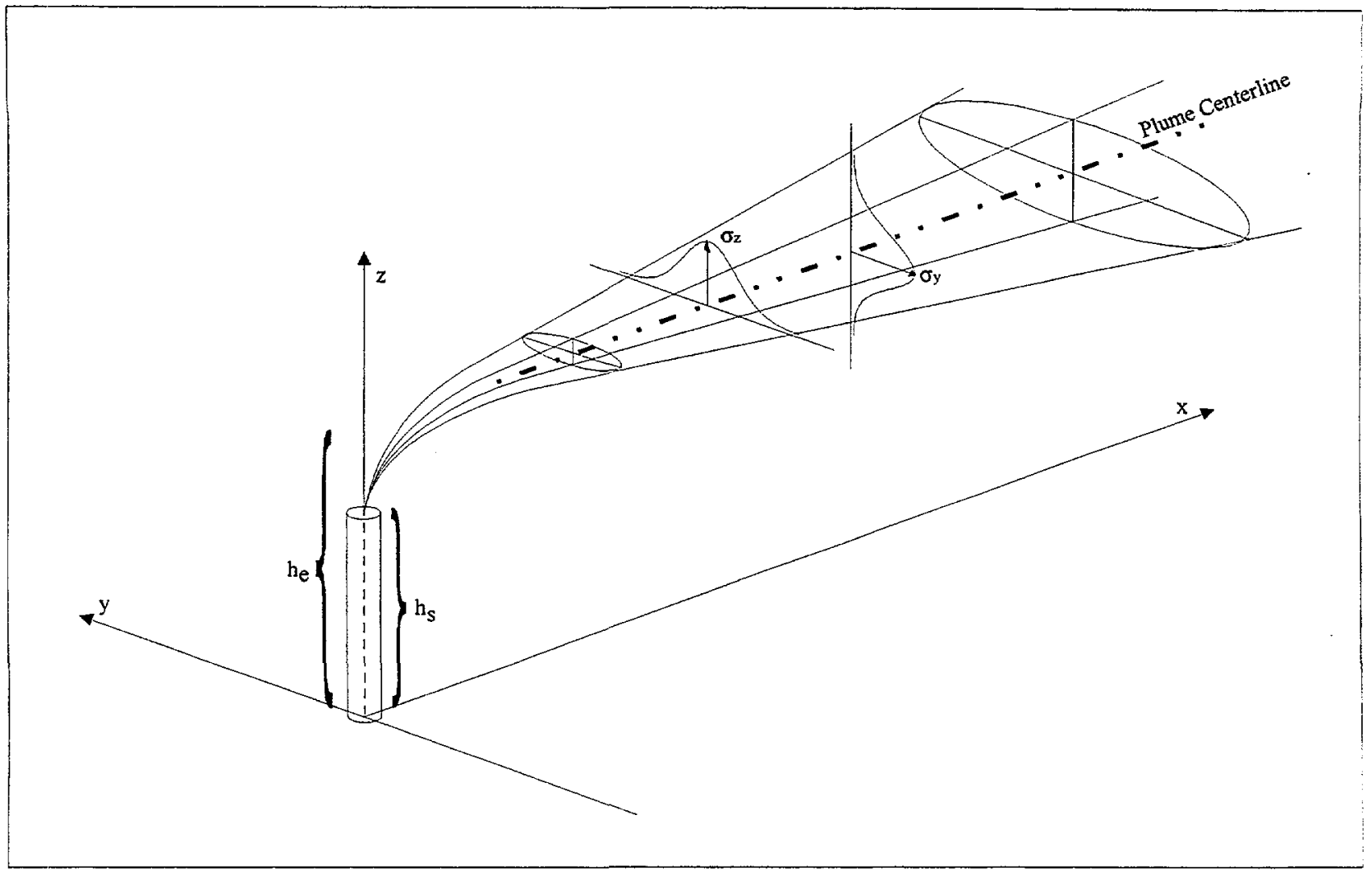

Figure 2. Gaussian Plume Dispersion Model

$$
\begin{aligned}
& \sigma_{y}=A_{y} x^{0.9031} \\
& \sigma_{z}=A_{z} x^{B_{z}}+C_{z}
\end{aligned}
$$

where $\mathrm{A}, \mathrm{B}, \mathrm{C}$ are fitting coefficients and $\mathrm{x}$ is the downwind distance. The fitting coefficients are given in Table III for three distances: less than $100 \mathrm{~m}, 100$ to $1000 \mathrm{~m}$, and greater than $1000 \mathrm{~m}$.

\begin{tabular}{|c|c|c|c|c|c|c|c|c|c|c|}
\hline \multirow{2}{*}{$\begin{array}{l}\text { Stability } \\
\text { Class }\end{array}$} & \multirow{2}{*}{$\overline{\mathbf{A}_{\mathbf{y}}}$} & \multicolumn{3}{|c|}{$\overline{\mathbf{A}_{\mathbf{z}}}$} & \multicolumn{3}{|c|}{$\overline{\mathbf{B}_{\mathbf{z}}}$} & \multicolumn{3}{|c|}{$\overline{C_{z}}$} \\
\hline & & $<100$ & 100 to $1000 \mathrm{~m}$ & $>1000 \mathrm{~m}$ & $<100 \mathrm{~m}$ & 100 to $1000 \mathrm{~m}$ & $>1000 \mathrm{~m}$ & $<100 \mathrm{~m}$ & 100 to $1000 \mathrm{~m}$ & $>1000 \mathrm{~m}$ \\
\hline$A$ & 0.3658 & 0.192 & 0.00066 & 0.00024 & 0.936 & 1.941 & 2.094 & 0 & 9.27 & -9.6 \\
\hline$\overline{\mathrm{B}}$ & 0.2751 & 0.156 & 0.0382 & 0.055 & 0.922 & 1.149 & 1.098 & 0 & 3.3 & 2 \\
\hline $\bar{C}$ & 0.2089 & 0.116 & 0.113 & 0.133 & 0.905 & 0.911 & 0.911 & 0 & 0 & 0 \\
\hline JD & 0.1471 & 0.079 & 0.222 & 1.26 & 0.881 & 0.725 & 0.516 & 0 & -1.7 & -13 \\
\hline$\overline{\mathrm{E}}$ & 0.1046 & 0.063 & 0.211 & 6.73 & 0.871 & 0.678 & 0.305 & 0 & -1.3 & -34 \\
\hline $\bar{F}$ & 0.0722 & 0.053 & 0.086 & 18.05 & 0.814 & 0.74 & 0.18 & 0 & -0.35 & -48.6 \\
\hline $\bar{G}$ & 0.0481 & 0.032 & 0052 & 10.83 & $\overline{0.814}$ & 0.74 & 018 & 0 & -0.21 & -29.2 \\
\hline
\end{tabular}

Table III. Fitting Coefficients for Dispersion Factors (Hey 1994) 
Several numerical codes use these equations or similar equations (which may account for building wake effects, plume meander, etc.) to compute the concentration of a contaminant to a receptor downwind from the release point. As shown, Eqs. 3 and 4 do not incorporate plume meander or building wake effects.

The dispersion calculations conducted in the SAR for non-routine, accident release scenarios followed the format suggested in Nuclear Regulatory Guide (NRG) 1.145, "Atmospheric Dispersion Models for Potential Accident Consequence Assessments at Nuclear Power Plants," Revision 1, November 1982 (NRC 1982). This a slight modification of the Gaussian model described above. The guide suggests a site-specific relative concentration $(\chi / Q)$ be determined based on atmospheric conditions of the site. For neutral (D) or stable (E, F, or G) atmospheric stability conditions for windspeeds less than $6 \mathrm{~m} / \mathrm{s}(3.1 \mathrm{knots})$ the $\chi / \mathrm{Q}$ value should follow the procedure described below.

$$
\begin{aligned}
& \chi / Q=\frac{1}{\overline{U_{10}}\left(\pi \sigma_{y} \sigma_{z}+A / 2\right)} \\
& \chi / Q=\frac{1}{\overline{U_{10}}\left(3 \pi \sigma_{y} \sigma_{z}\right)} \\
& \chi / Q=\frac{1}{\overline{U_{10}}\left(\pi \Sigma_{y} \sigma_{z}\right)}
\end{aligned}
$$

where,

$\chi / \mathrm{Q}=$ relative concentration $\left(\mathrm{s} / \mathrm{m}^{3}\right)$

$\mathrm{U}_{10}=$ windspeed $(\mathrm{m} / \mathrm{s})$ at $10 \mathrm{~m}$ above the ground

$\sigma_{y}=$ lateral plume spread (m), a function of atmospheric stability and distance

$\sigma_{z}=$ vertical plume spread (m), a function of atmospheric stability and distance 
$\Sigma_{\mathrm{y}}=$ lateral plume spread with meander and building wake effects $(\mathrm{m})$, a function of atmospheric stability and distance. For $800 \mathrm{~m}$ and less: $\Sigma_{y}=M \sigma_{y}$, where $M$ is a correction factor determined from a lookup chart (NRC 1982). For greater than $800 \mathrm{~m}: \Sigma_{\mathrm{y}}=(\mathrm{M}-1) \sigma_{\mathrm{y} 800 \mathrm{~m}}+\sigma_{\mathrm{y}}$.

$A=$ vertical plane cross-sectional area of release vent $\left(\mathrm{m}^{2}\right)$.

$\chi / \mathrm{Q}$ should be calculated using all three equations. The values from Eq. 7 should be compared to Eq. 8, and the largest value selected. The result is then compared to Eq. 9 and the smallest value selected. For wind stability classes of A, B, or C, only Eq. 7 and Eq. 8 need to be compared and the largest value selected.

Intuitively, it is easy to see that the conditional use of Eqs. 7-9 is not the most conservative combination; using the largest value of the three would always insure conservatism in the calculation of the site-specific air dispersion factor. However, the NRC RG 1.145 gives rationale for the selection of the most appropriate equation, citing 1) horizontal plume meander tends to dominate dispersion during light wind and stable or neutral conditions, and 2) building wake mixing becomes more effective in dispersing effluents than meander effects as the windspeed increases and the atmosphere becomes less stable (16).

The SAR reported a $\chi / \mathrm{Q}$ value of $5.11 \times 10^{-3} \mathrm{~s} / \mathrm{m}^{3}$ at $100 \mathrm{~m}$ for conditions of stability class $\mathrm{F}$, windspeed $=1.5 \mathrm{~m} / \mathrm{s}, \sigma_{\mathrm{y}}=4.6 \mathrm{~m}, \sigma_{\mathrm{z}}=2.3 \mathrm{~m}, \mathrm{M}=4$, and $\mathrm{A}=117 \mathrm{~m}^{2}$. At the time of the 1996 SAR update, sufficient meteorological data had not existed. The analyses relied on values of stability class and windspeed provided in DOE handbooks. However, since 1996, over three years of quality meteorological data exists and that data was used in formulating a PDF for windspeeds of the six stability classes. The next section describes the general meteorological conditions at WIPP.

\subsection{General Description of Meteorological Conditions at WIPP}

The meteorological conditions at WIPP vary from day-to-day and from season-to-season. 


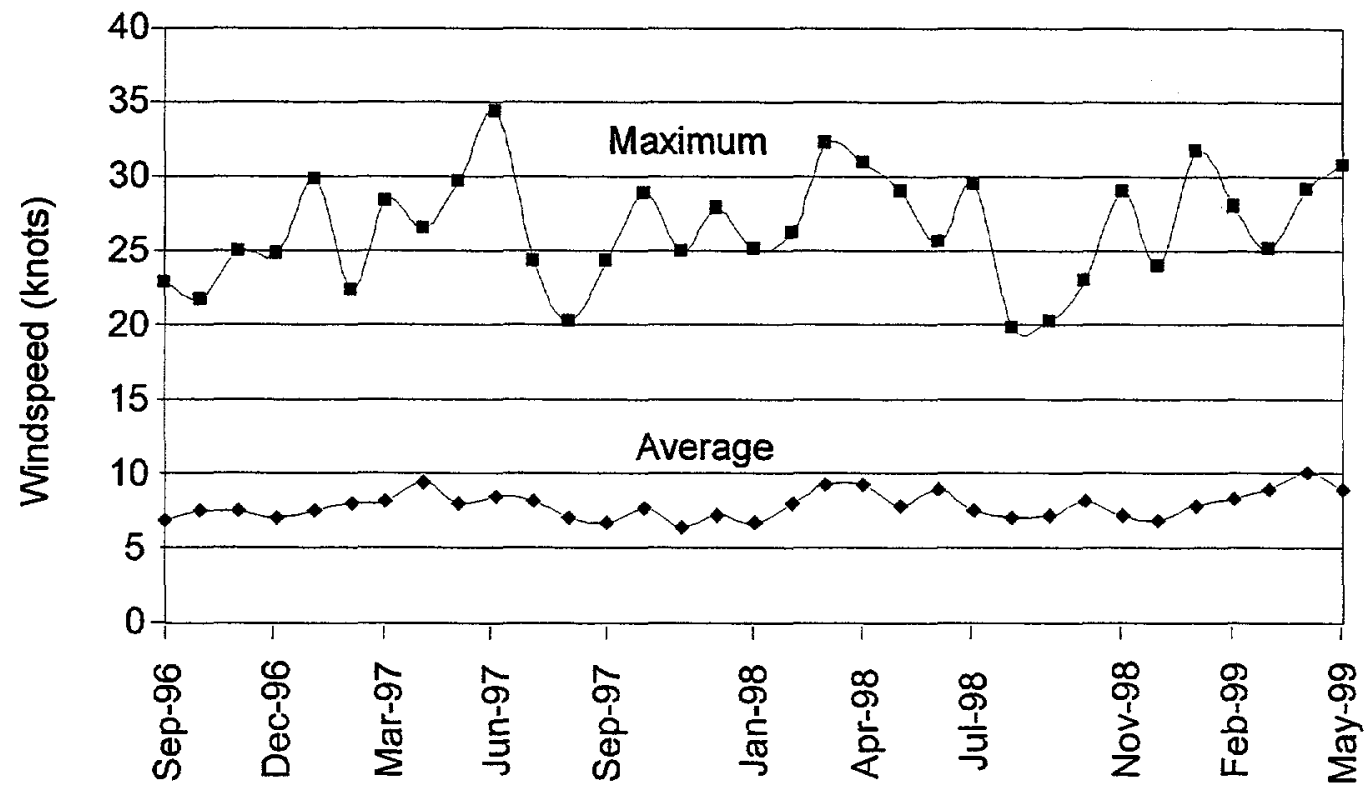

Figure 3. Maximum and Average (over an entire month) Wind Speed at WIPP for the Period of September 1996 to May 1999.

Generally, however, one could expect variable wind speeds from the southeast with approximately 12 inches of precipitation per year. The region is characterized by an arid to semiarid climate, as is most of the southwestern United States.

\subsubsection{Wind Speed}

The windspeed around the WIPP site generally varies between 0 to $16 \mathrm{knots}$, averaging approximately $8 \mathrm{knots}$, and rising as high as 34 knots. Spring is the windiest time in the region, with April and May having the highest wind speeds, whereas summer brings about calmer winds. Figure 3 shows the average and maximum windspeeds for the period of September 1996 to May 1999.

Wind speed is important in three regards: dilution of a contaminant plume, which takes place in the direction of the plume transport; the transport time of the plume to the receptor (person or measuring device subjected to plume hazard); and buoyant plume rise - the stronger the wind the lower the plume. 


\subsubsection{Air Temperature}

The air temperature at WIPP is temperate, rarely dropping below $20^{\circ} \mathrm{F}\left(-6.7^{\circ} \mathrm{C}\right)$ in the winter months. The maximum air temperature can reach as high as $120^{\circ} \mathrm{F}\left(48.9^{\circ} \mathrm{C}\right)$ in late summer. Figure 4 shows the minimum, average, and maximum monthly temperatures at WIPP for the months spanning September 1996 to May 1999, taken at the $10 \mathrm{~m}$ level.

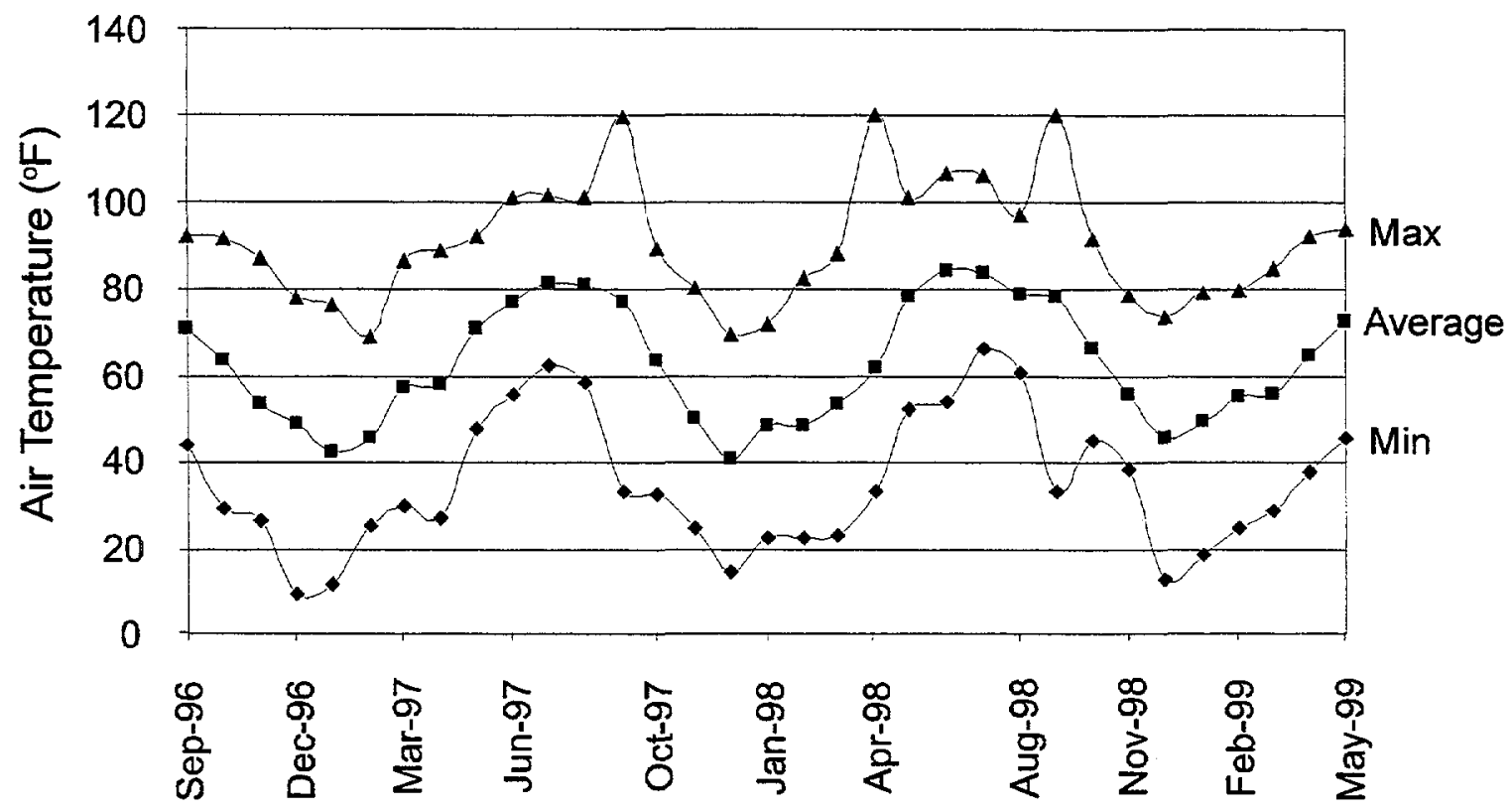

Figure 4. Monthly Minimum, Average, and Maximum Air Temperatures at WIPP for the Period of September 1996 to May 1999.

The wind stability class is a measure of resistance to vertical mixing. The wind stability is usually classified by determining the change in temperature to the change in height (IAEA 1980, EPA 1987). Usually very stable air is undesirable; pollutants are not able to dilute through mixing and transport.

The stability classes are defined in Table IV. A calculation is made, determining the change in ternperature per $100 \mathrm{~m}$. For the WIPP classification, the temperature difference was taken at 50 $\mathrm{m}$ and $10 \mathrm{~m}$ and the conversion is demonstrated in Eq. 10 . 


$$
\Delta \mathrm{T} / \Delta \mathrm{z}=\left(\mathrm{T}_{50}-\mathrm{T}_{10}\right) * 2.5
$$

The stability class at WIPP spans the whole spectrum from $A$ to $G$, but is neutral or stable about two-thirds of the time. Table V shows the percentage of time that the wind is in each category.

Table IV. Classification of Atmospheric Stability (NRC 1972)

\begin{tabular}{|l|c|l|}
\hline Stability Classification & Category & $\Delta \mathbf{T} / \Delta \mathbf{z}\left({ }^{\circ} \mathbf{C} / \mathbf{1 0 0} \mathbf{~ m}\right)$ \\
\hline Extremely Unstable & A & $<-1.9$ \\
\hline Moderately Unstable & B & -1.9 to -1.7 \\
\hline Slightly Unstable & C & -1.7 to -1.5 \\
\hline Neutral & D & -1.5 to -0.5 \\
\hline Slightly Stable & E & -0.5 to 1.5 \\
\hline Moderately Stable & F & 1.5 to 4.0 \\
\hline Extremely Stable & G & $>4.0$ \\
\hline
\end{tabular}

Table V. WIPP Stability Class Designation for September 1996 to May 1999 by Percentage of Time

\begin{tabular}{|c|c|}
\hline Stability Class & Percentage of Time in Each Category \\
\hline A & 22.02 \\
\hline B & 5.21 \\
\hline C & 4.88 \\
\hline D & 16.35 \\
\hline E & 18.28 \\
\hline F & 13.47 \\
\hline
\end{tabular}

The PDF for the meteorological conditions of windspeed at WIPP was determined by the data presented above. Figures 5 a through $5 \mathrm{~g}$ show the windspeed distributions for each stability class. In the spreadsheet calculations, the $\chi / Q$ for each wind stability class was weighted according to Table V. 

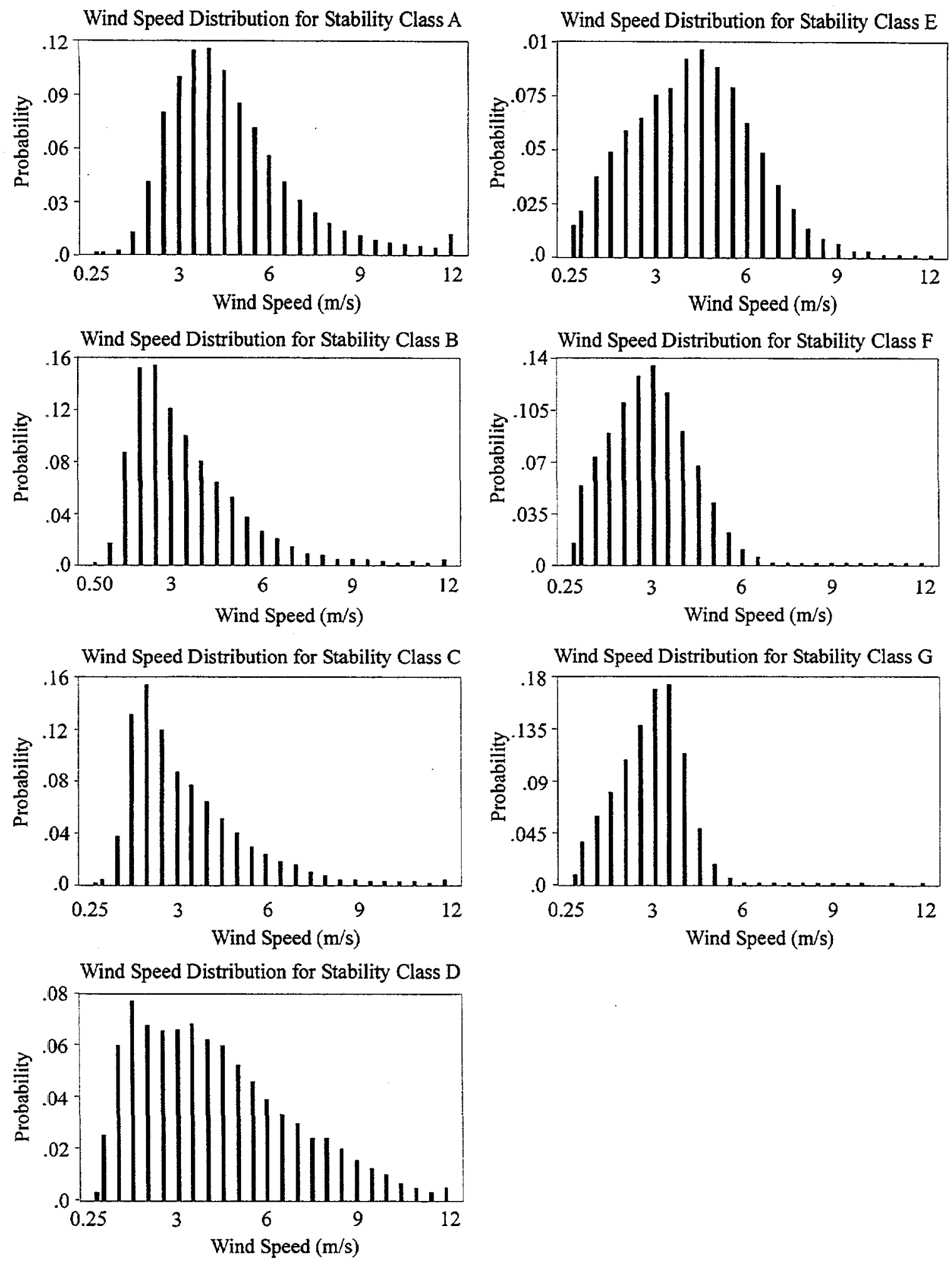

Figure $5 \mathrm{a}$ through $5 \mathrm{~g}$. Wind speed distributions separated by stability classes. 


\subsubsection{Wind Direction}

The wind direction is simply the direction from which the wind blows. The wind direction is usually designated into 16 categories, starting from $\mathrm{N}$ (orth) and going clockwise to NNE, NE... as seen in Figure 6.

The polar plot of Figure 6 shows the direction from which direction the wind blows for all data between September 1996 and May 1999. In general, the wind is from the southeast and eastsoutheast at the WIPP site. The spreadsheet calculations for $\chi / Q$, however, did not consider the direction from which the wind comes.

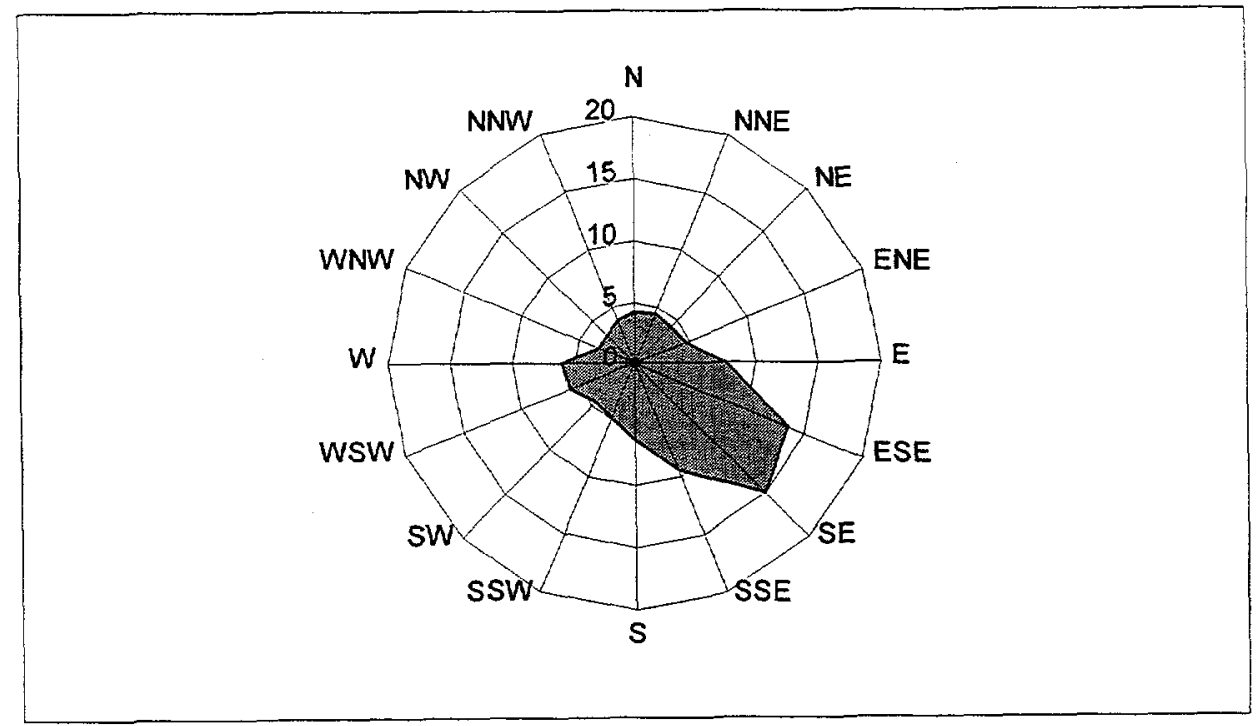

Figure 6. Percentage of Wind Direction (from Direction Indicated) for Meteorological Data of September 1996 to May 1999.

\subsubsection{Precipitation}

The amount of rainfall at the WIPP site varies significantly from month to month and year to year with 1997 being an extremely wet year at 23.9 inches $(607.3 \mathrm{~mm})$ and 1998 being an extremely dry year at 7.7 inches $(195.6 \mathrm{~mm}$ ). The average rainfall is about 10-12 inches (254- 


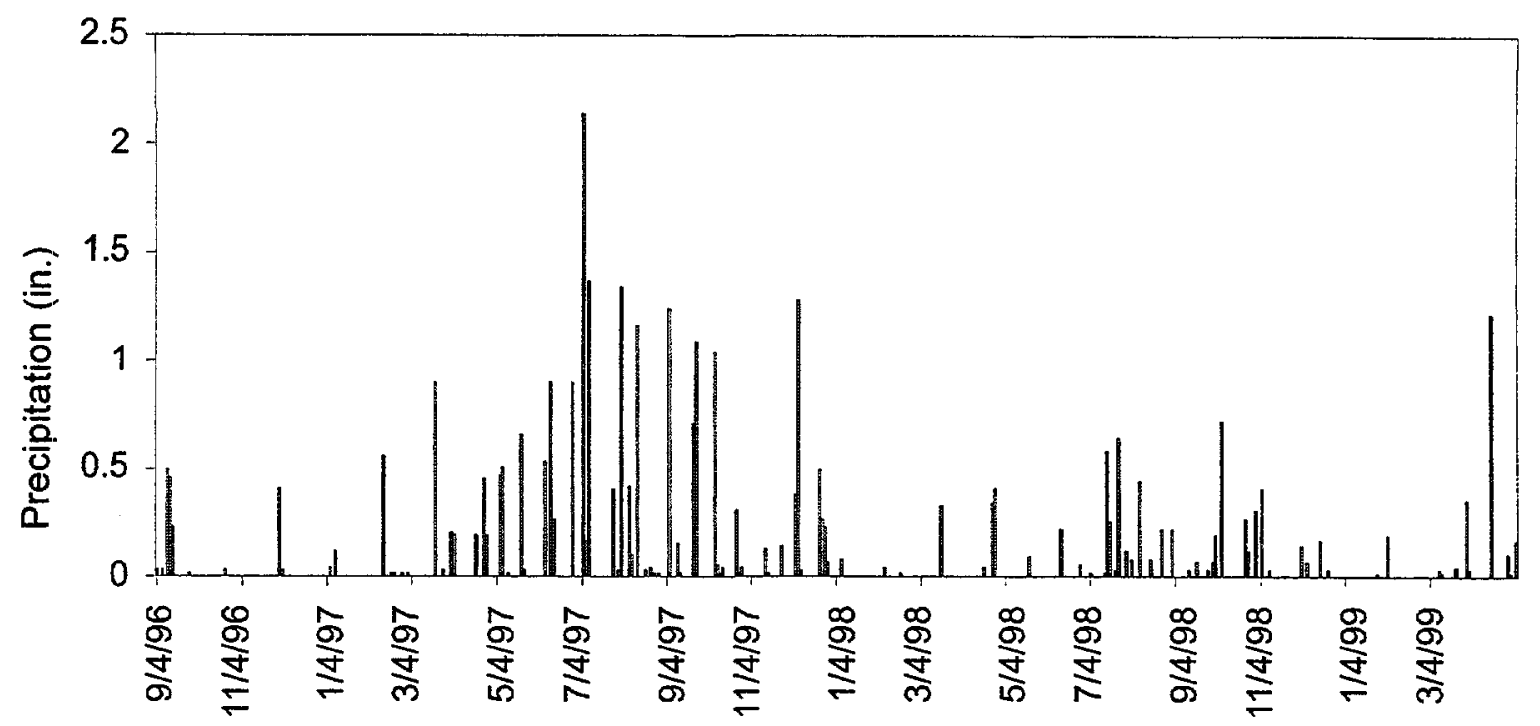

Figure 7. Daily Precipitation Record (in Inches) at WIPP from September 1996 to May 1999.

$305 \mathrm{~mm}$ ) per year. Figure 7 shows daily precipitation data for the period of September 1996 to May 1999. Again, precipitation was not used in formulating $\chi / Q$.

\subsection{Source Term}

The formulation of the source term for the PSA remained consistent with the SAR. The only change was the use of a PDF to represent the actual drum loading expected from each generator site as reported in the Baseline Inventory Report (BIR), Rev. 3 (DOE 1995). The source term, $\mathrm{Q}$ in $\mathrm{Ci}$, was calculated by

$\mathrm{Q}=\mathrm{MAR} * \mathrm{DR} * \mathrm{ARF} * \mathrm{RF} * \mathrm{LPF}$

where MAR is the material at risk ( $\mathrm{Ci}$ ) and is calculated by the curie content of a drum multiplied by the number of drums involved in the accident. DR is the damage ratio and is the fraction of the MAR that is impacted by the accident. ARF is the airborne release fraction and is the fraction of radioactive material that is suspended in air resulting from the accident. RF is the respirable fraction, which relates to the fraction of particles that are in the respirable 
range (less than $10 \mu \mathrm{m}$ AMAD). LPF is the leakpath factor and is the fraction of material that is not filtered out of the air after the accident. Filtering for an above ground accident occurs in permanently installed, continuous on-line two-stage HEPA filtration system. Filtering for an underground accident is only engaged during an accident. LPF is assumed to be $1 \times 10^{-6}$ for the mitigating case (filtered) and 1.0 for unmitigated release (DOE 1999). This reports assumes that all accidents for the probabilistic dose assessment are unmitigated for comparison with the SAR.

Figure 8 shows a conceptual model of assessing the source for an inhalation dose from the drum curie content. The figure is a reproduction of the one presented in Mueller et al. (1994).

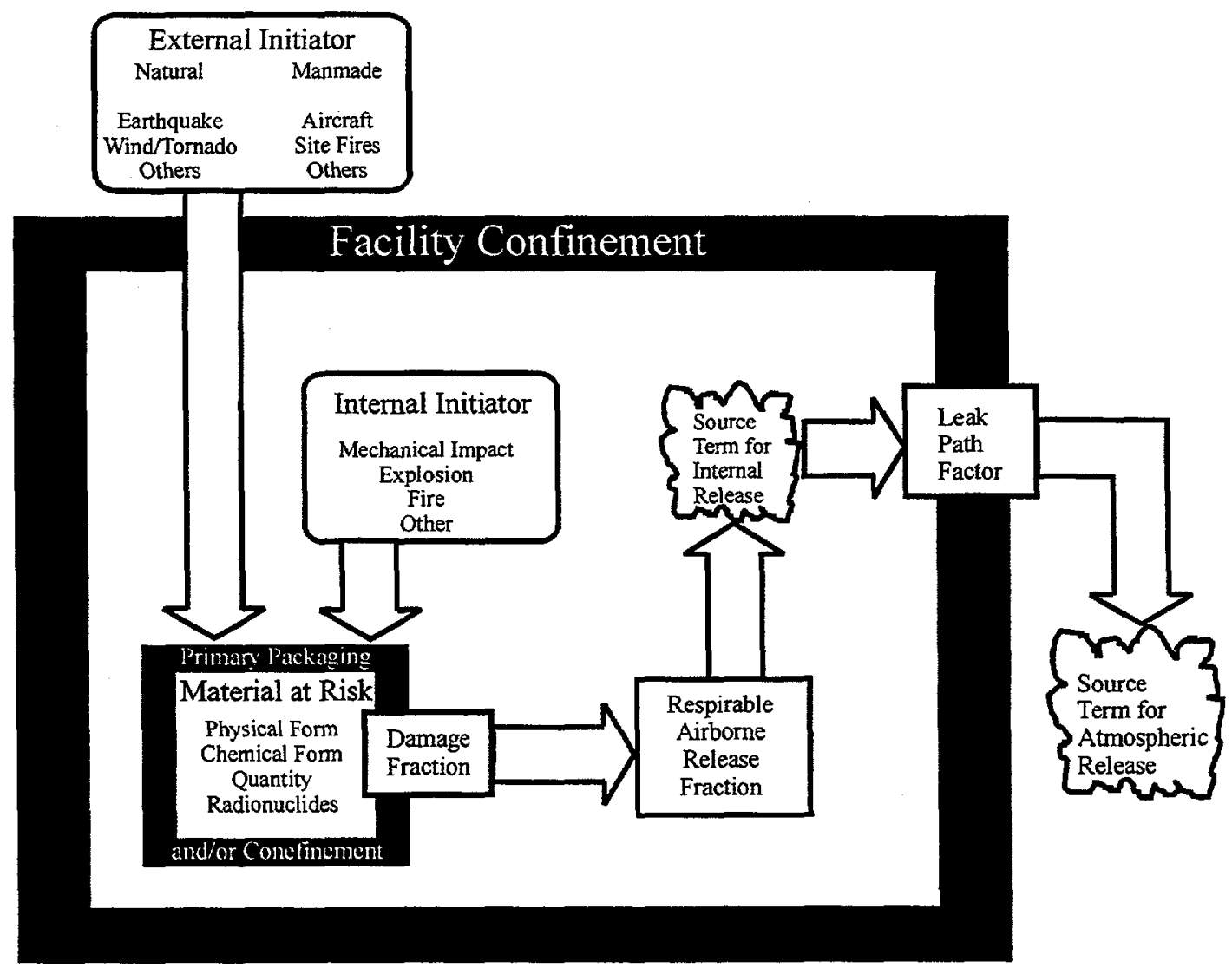

Figure 8. Conceptual model for source term development 
The waste form of each drum and each type of accident dictates the values for DR, ARF, and $\mathrm{RF}$ and are taken from the DOE handbook on airborne releases (DOE 1994b). Table VI lists some examples of values used in the three parameters and the product of the three. The values from Table VI were used in formulating the source term for the dose calculations.

Table VI. Example DR, ARF, and RFs used in formulating the source term.

\begin{tabular}{|l|c|c|c|c|}
\hline Waste Form & DR & ARF & RF & Overall Product \\
\hline $\begin{array}{l}\text { Combustible Solids(95\%) drops less than } 5 \\
\mathrm{ft} \text { (drum) }\end{array}$ & $1 \times 10^{-2}$ & $1 \times 10^{-3}$ & $1 \times 10^{-1}$ & $1 \times 10^{-6}$ \\
\hline $\begin{array}{l}\text { Noncombustible Solids(95\%) drops less than } \\
10 \mathrm{ft} \text { (SWBs/overpacks) }\end{array}$ & $1 \times 10^{-2}$ & $1 \times 10^{-3}$ & 1.0 & $1 \times 10^{-5}$ \\
\hline $\begin{array}{l}\text { Solidified Solids, Vehicle Impact and } \\
\text { Puncture }\end{array}$ & $1 \times 10^{-2}$ & $2 \times 10^{-5}$ & N.A. & $2 \times 10^{-7}$ \\
\hline $\begin{array}{l}\text { Noncombustible Solids(95\%) drops } 2000 \mathrm{ft} \\
\text { (waste hoist) }\end{array}$ & $2.5 \times 10^{-1}$ & $1 \times 10^{-3}$ & 1.0 & $2.5 \times 10^{-4}$ \\
\hline
\end{tabular}

The curie content of each drum from all major generator sites was estimated from the BIR and a PDF was assigned respectively. Fig. 9a-9i shows example probability density functions (PDFs) of the nine generator sites' expected drum loading. For the PSA, a total of nine generator sites were evaluated, including Idaho National Engineering Laboratory (INEEL), Los Alamos National Laboratory (LANL), Lawrence Livermore National Laboratory (LLNL), Mound Site (MD), Nevada Test Site (NTS), Oak Ridge National Laboratory (ORNL), Rocky Flats Environmental Test Site (RFETS), Richland Site in Hanford (RL), and Savannah River Site (SRS). The PDFs shown in Fig. 9 are for the entire expected population of drums to arrive at WIPP as reported in the BIR (DOE 1995). Fig. 9 was created from the observed frequency normalized to the total population.

The source term from each generator site was multiplied by a weighting factor, which normalized the value to the expected number of curies from each site. Table VII shows the weighted fraction used in formulating the source term. 
a) Drum Curie Content at INEEL

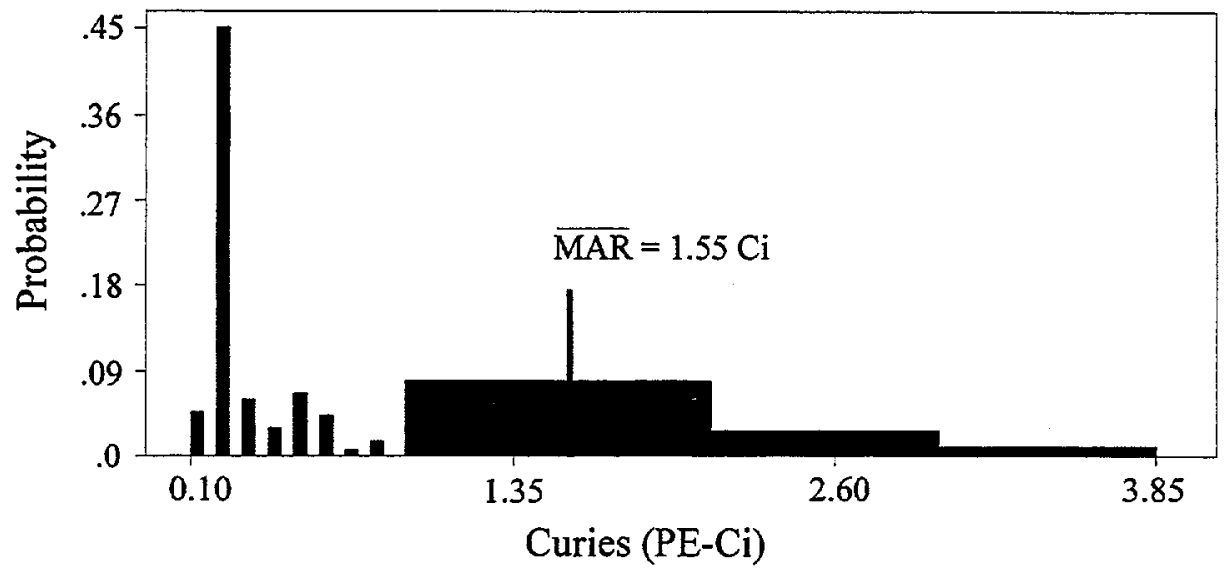

b) Drum Curie Content at LANL

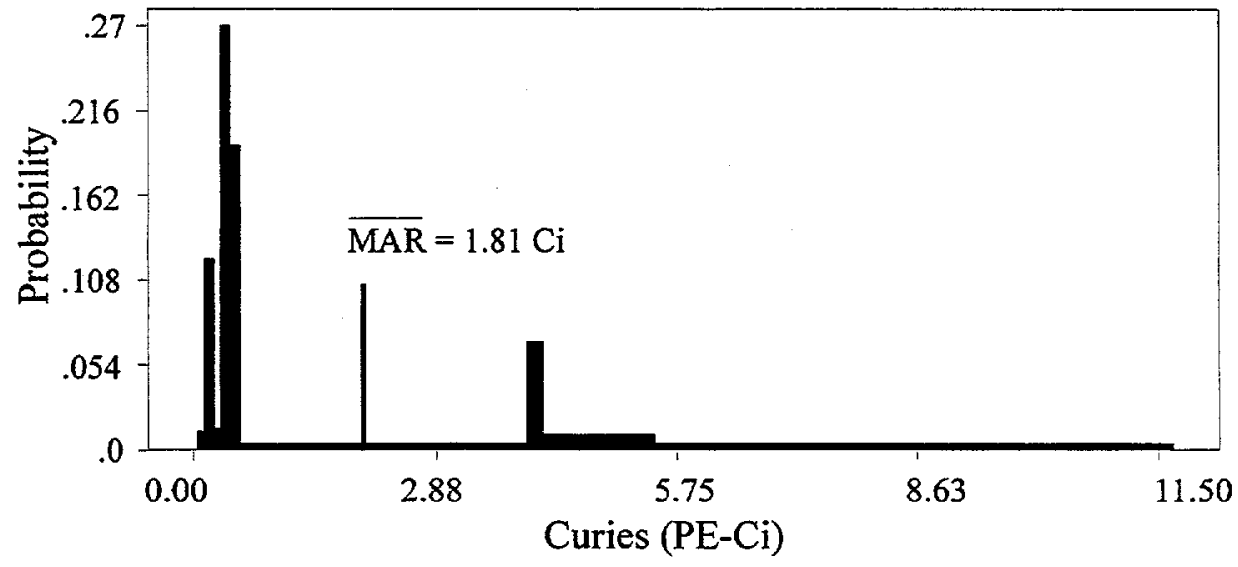

c) Drum Curie Content at LLNL

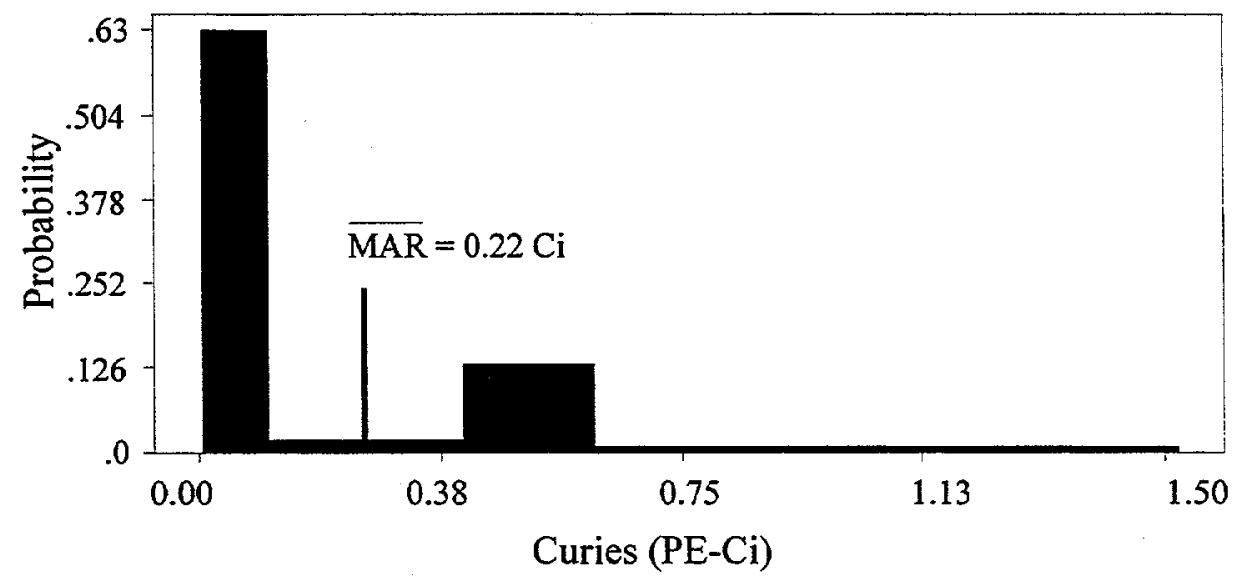

Figures $9 a$ through $9 c$. PDFs of the various generator sites. 
d) Drum Curie Content at $\mathrm{MD}$

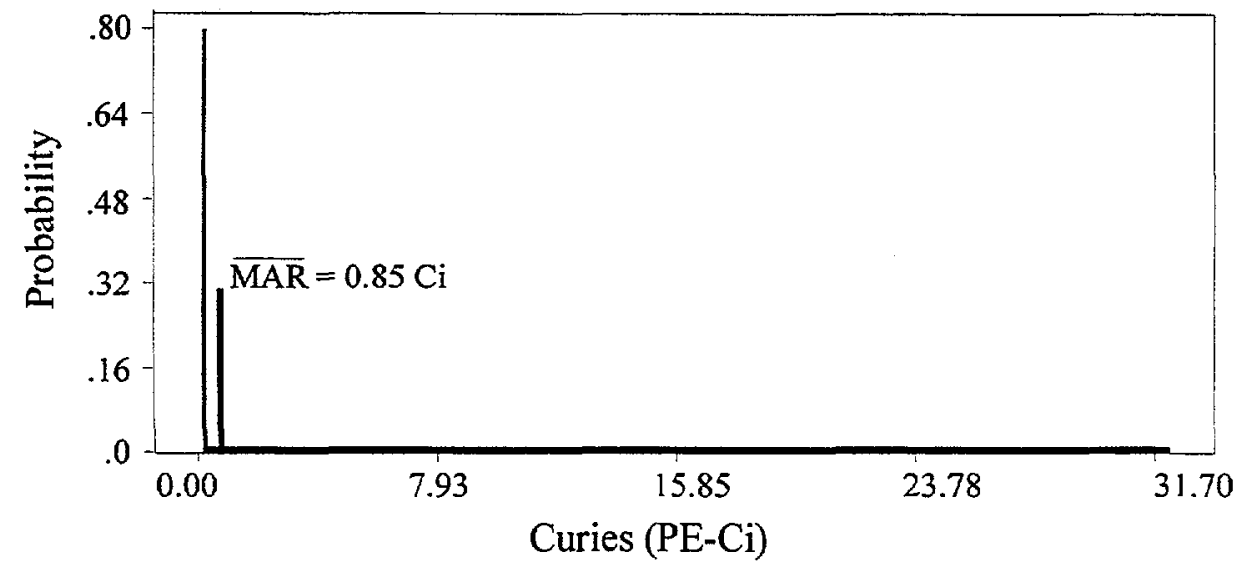

e) Drum Curie Content at NTS

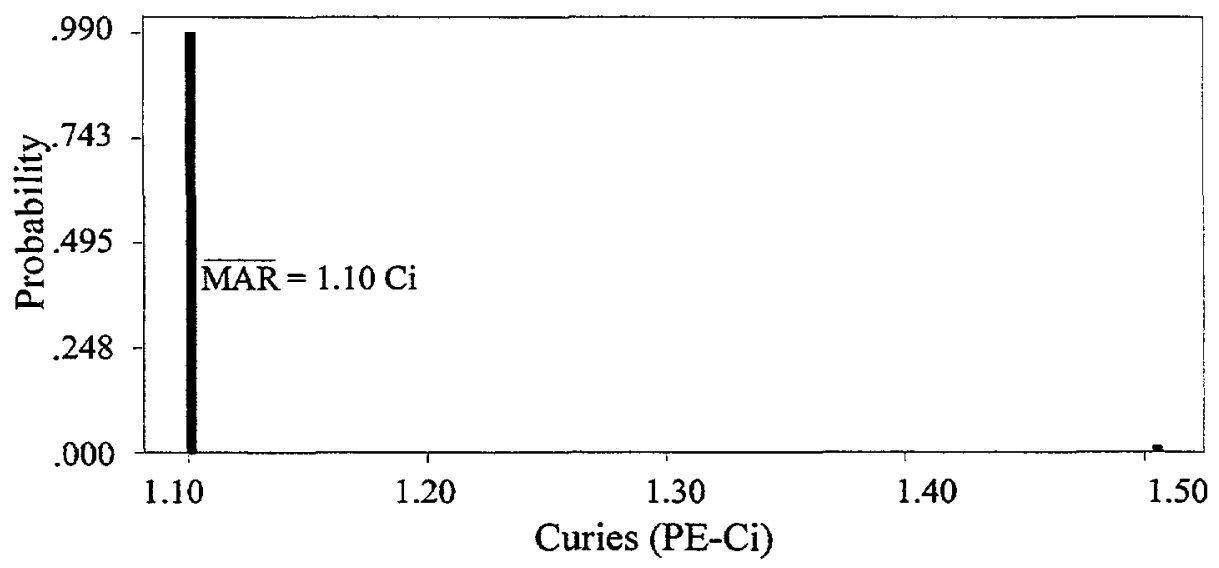

f) Drum Curie Content at ORNL

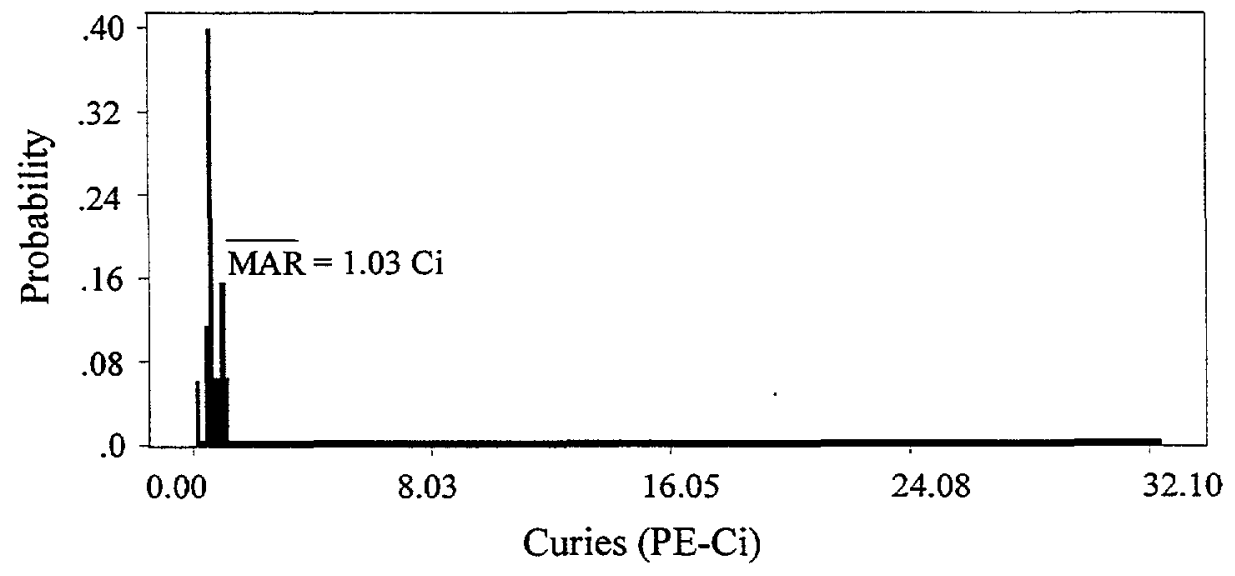

Figures 9d through 9f. PDFs of the various generator sites. 
g) Drum Curie Content at RFETS

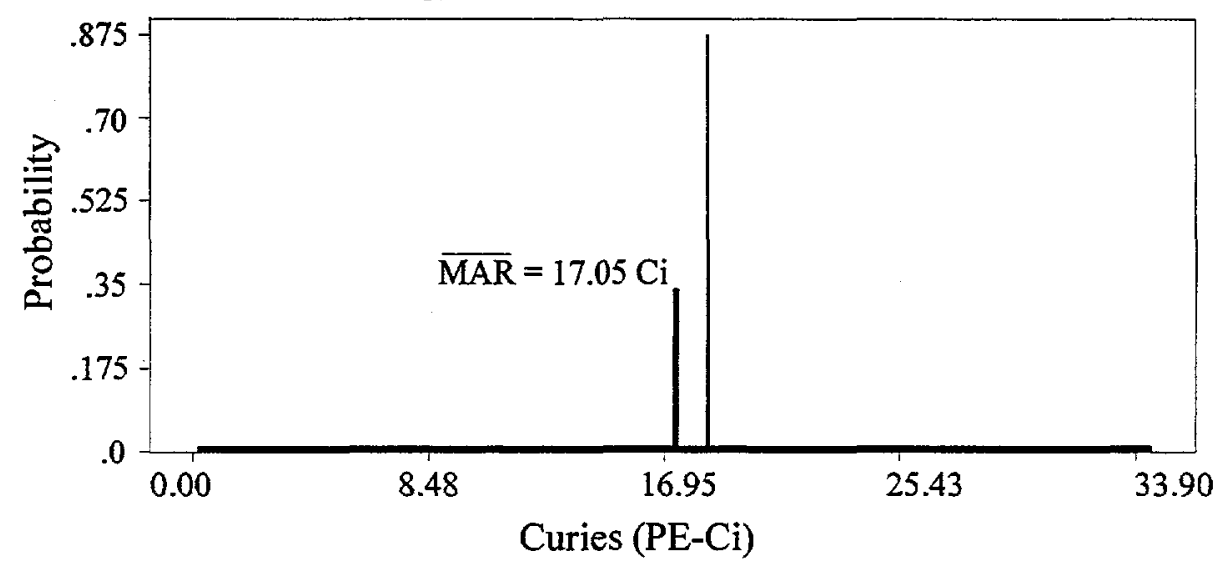

h) Drum Curie Content at RL

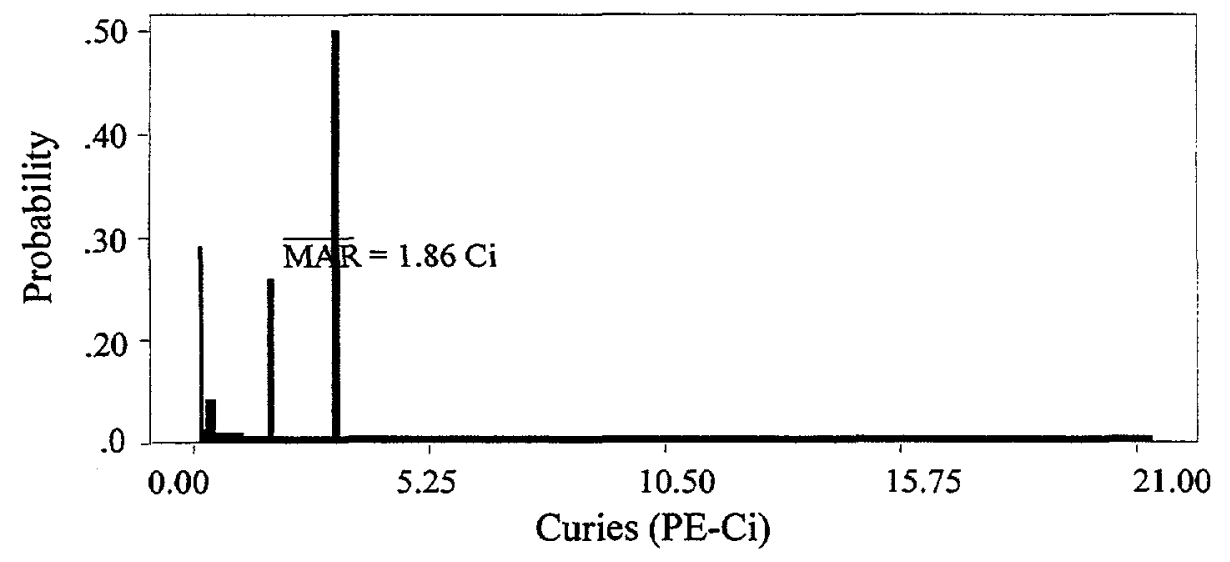

i) Drum Curie Content at SRS

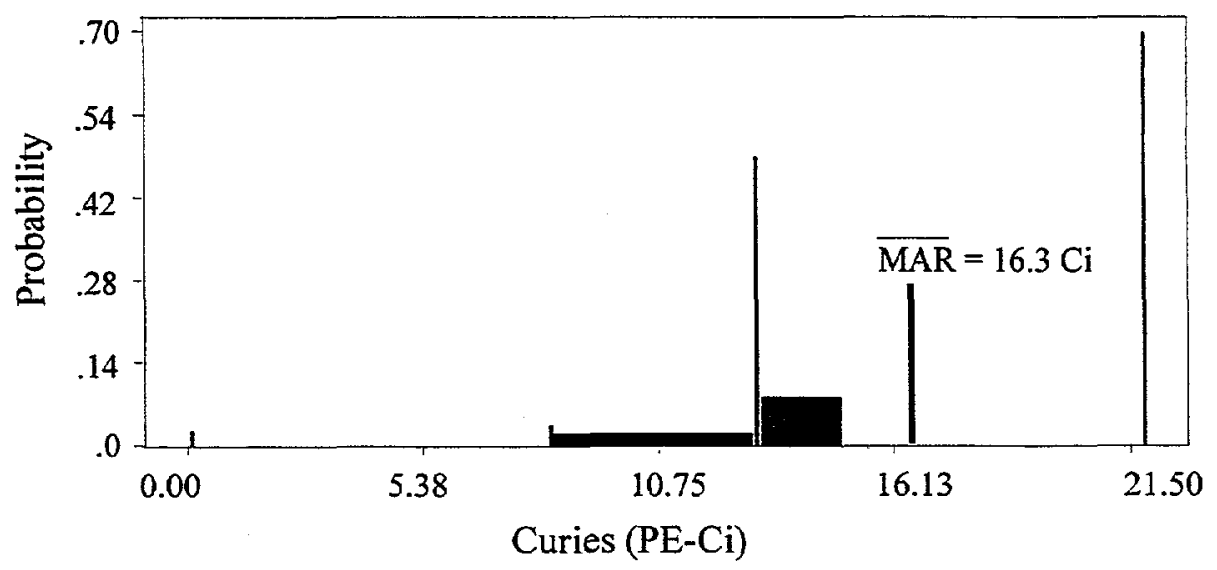

Figures $9 \mathrm{~g}$ through $9 \mathrm{i}$. PDFs of the various generator sites. 
Table VII. Weighted fraction used in formulating the source term.

\begin{tabular}{|l|c|c|}
\hline Site & Curies At Each Site & Fraction of Total Curies \\
\hline$\overline{\mathrm{IN}}$ & 195980 & 0.161 \\
\hline $\mathrm{LA}$ & 104275 & 0.0857 \\
\hline $\mathrm{LL}$ & 292 & 0.000240 \\
\hline $\mathrm{MD}$ & 1419 & 0.00117 \\
\hline $\mathrm{NT}$ & 3190 & 0.00262 \\
\hline $\mathrm{OR}$ & 7805 & 0.00641 \\
\hline $\mathrm{RF}$ & 382761 & 0.315 \\
\hline $\mathrm{RL}$ & 109161 & 0.0898 \\
\hline SR & 411191 & 0.3381 \\
\hline TOTAL & 1216074 & 1.00 \\
\hline
\end{tabular}

\subsection{Discretization}

The lateral distance from the source was incorporated into the site-specific air dispersion calculations by discretizing a 1-D grid by $50 \mathrm{~m}$ increments, starting at $100 \mathrm{~m}$ from the source to $500 \mathrm{~m}$. The final results (Figure 11) will show dose versus distance. 


\section{DISCUSSION}

Once all of the proper information was entered into the spreadsheet, including the site-specific meteorological data and the source term data, the Monte Carlo simulation was run by randomly sampling 10,000 iterations from each PDF. The spreadsheet was divided by the 6 stability classes and each stability class was discretized into the $50-\mathrm{m}$ distances, starting at $100 \mathrm{~m}$ and ending at $500 \mathrm{~m}$ ( 9 total grid points). Within each distance column, the nine generator sites were sampled for drum loading and the source term was calculated accordingly. A total of 486 PDFs ( 9 generating sites $\times 6$ stability classes $\times 9$ spatial grid points) were sampled 10,000 times and the statistical information was retained from the sampling. The large number was chosen to more accurately represent each distribution.

The final result was a matrix of dose forecasts, showing the doses resulting from all scenarios, versus distance. A frequency histogram and a confidence interval further characterized each dose in the matrix. The histogram was compiled by keeping track of all calculated dose values and dividing them into discrete intervals. The intervals show the total count of dose calculation within that interval. The probability of dose for a specific interval can be calculated by normalizing the frequency by the total number of observations, which in this case is 10,000 .

Figure 10 shows four examples of frequency distributions with their associated probabilities. The four plots show -from upper left to lower right- doses expected from scenario $\mathrm{CH} 2$ if the receptor is $250 \mathrm{~m}$ from the source, doses expected from scenario $\mathrm{CH} 5$ at $100 \mathrm{~m}$ from the source, doses expected during scenario $\mathrm{CH} 7$ at $400 \mathrm{~m}$ from the source, and doses expected from scenario $\mathrm{CH} 11$ at $250 \mathrm{~m}$ from the source. The source in this example is the above ground exhaust shaft outlet or the outside ventilation of the WHB. The example plots of Figure 10 were not chosen for any special reason. They were randomly selected to give a representation of many scenarios. Table IX lists additional statistics for the four frequency distributions. 
Table IX. Statistics of Dose Calculations

\begin{tabular}{|l|r|r|r|r|}
\hline Statistics & CH2 at 250m & CH5 at 100m & CH7 at 400m & CH11 at 250m \\
\hline Trials & 10000 & 10000 & 10000 & 10000 \\
\hline Mean & 2.4 & 42.5 & 0.3 & 0.8 \\
\hline Median & 2.0 & 33.4 & 0.3 & 0.6 \\
\hline Standard Deviation & 4.3 & 92.2 & 1.0 & 1.4 \\
\hline Variance & 18.8 & 8496.4 & 1.1 & 1.9 \\
\hline Skewness & 43.74 & 27.51 & 38.41 & 43.74 \\
\hline Kurtosis & $2,651.26$ & $1,091.06$ & $1,711.01$ & $2,651.26$ \\
\hline Coeff. of Variability & 1.81 & 2.17 & 3.16 & 1.81 \\
\hline Dose Range Minimum & 0.8 & 13.5 & 0.1 & 0.2 \\
\hline Dose Range Maximum & 306.2 & 5034.6 & 53.8 & 96.2 \\
\hline Dose Range Width & 305.5 & 5021.1 & 53.7 & 96.0 \\
\hline
\end{tabular}

The main feature to note about the frequency distributions is that it is a lognormal distribution. Every distribution from the probabilistic dose assessment has this shape. The Central Limit Theorem proves this observation mathematically and states that the mean of a set of $n$ variables, where $\mathrm{n}$ is large, drawn independently from the same distribution will be normally distributed (Vose 1996). The product of a large number of independent positive variables drawn from different distributions will be approximately lognormally distributed.
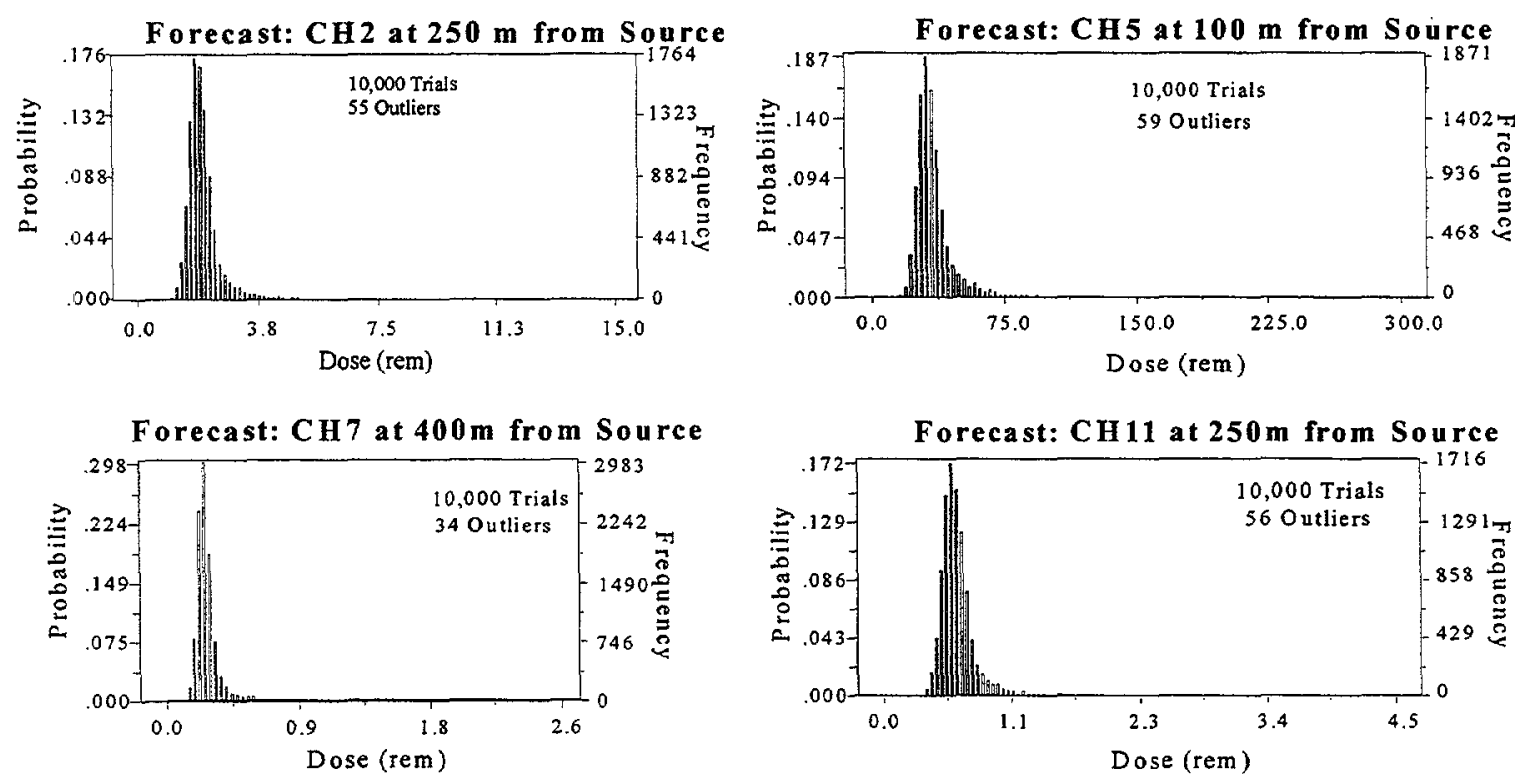

Figure 10. Inhalation dose distributions for selected scenarios. 
The confidence intervals for each set of scenarios were also calculated from the compiled information. The most meaningful representation of confidence is showing the $5 \%, 50 \%$, and $95 \%$ confidence limits, i.e., the expected dose that falls at or below that given confidence limit. Figure 11 shows all eight scenarios' expected dose including the confidence intervals described above. Each subplot in Figure 11 shows dose vs. distance, between $100 \mathrm{~m}$ and $500 \mathrm{~m}$ from the source at $50-\mathrm{m}$ grid points. The dose is in rem and represents the 50 -year whole body committed effective dose equivalent (CEDE). From Figure 11, one can see that the CH5 scenario is the most catastrophic event with a dose of 64 rem at $100 \mathrm{~m}$ from the source with a confidence that $95 \%$ of the doses fall at or below $64 \mathrm{rem}$. CH5 is the waste hoist scenario, where the hoist plummets $655 \mathrm{~m}$ with 28 drums. The WIPP SAR calculated a dose of $61 \mathrm{rem}$ at $100 \mathrm{~m}$ (Table II) and is approximately equal to the probabilistic dose assessment.

Other scenarios, such as the $\mathrm{CH} 1$ and $\mathrm{CH} 7$ show that the SAR is conservative in its estimate of dose. The SAR's version of the CH1 scenario, where a drum spontaneously ignites in the WHB, is represented by a dose of $33 \mathrm{rem}$ at $100 \mathrm{~m}$ (Table II). The dose calculated in the present study is 4.6 rem with a $95 \%$ confidence limit. Similarly, the dose estimate for $\mathrm{CH} 7$ in the SAR is approximately 7 times greater than calculated in Figure 11. 

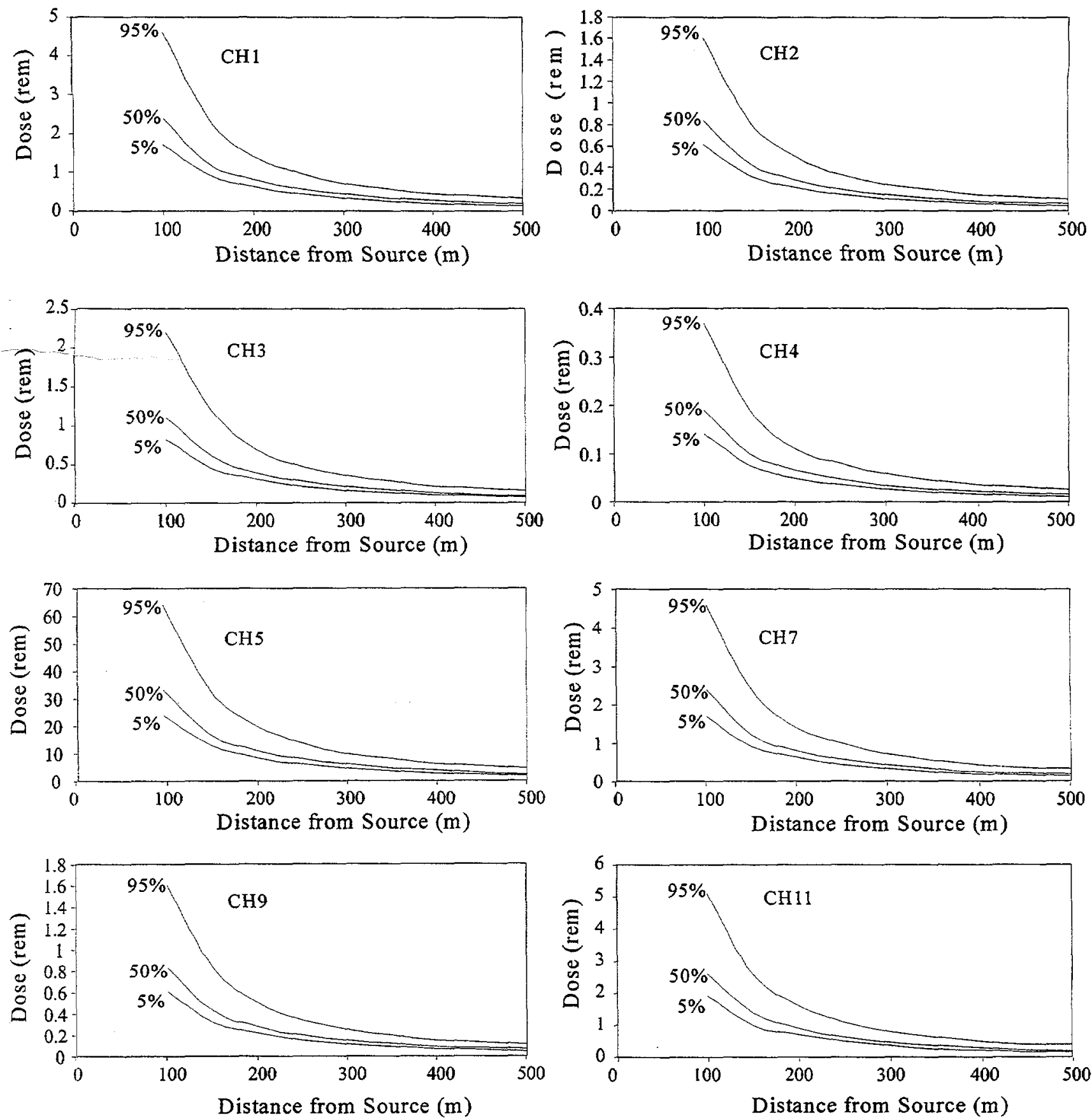

Figure 11. Probabilistic dose vs. distance for the eight accident scenarios with $5 \%, 50 \%$, and $95 \%$ confidence limits. 


\section{CONCLUSIONS}

The radioactive dose to an individual for various accident scenarios was calculated using a probability model for Eq. 1. Two of the four input parameters of Eq. 1. were assigned ranges of expected values; the remaining two were constant. A probability density function (PDF) was assigned to each data range to appropriately represent the uncertainties of the problem. A Monte Carlo simulation was employed to randomly sample from the range of values as dictated by the PDF. A large number of samples were chosen to more accurately mimic the behavior of each PDF. Hence, a large number of dose calculations were performed and statistical information was derived for the set of calculations. The results, displayed in Fig. 4., show a dose versus distance from the source of release of radioactivity for each plausible scenario in the WIPP SAR (DOE 1999), given site-specific meteorological conditions and expected radioactive content of each drum involved.

This technique was different than that presented in the WIPP SAR (DOE 1999). The SAR listed deterministically calculated dose, where single-point parameter values were used in modeling Eq. 1. The values for this type of modeling can be "best-guess" estimates, but the SAR chose to use conservative values in their calculations to bound the expected radioactive uptake and dose to a downwind receptor. The calculations for the SAR are shown in Table II, and the unmitigated dose can be compared to Figure 11.

In addition to the deterministic calculations, the SAR presented a limited sensitivity analysis of the effect of different drum activity loading. For example, Table II shows scenario $\mathrm{CH} 4$ with three sets of calculations: 1) the base case with 1 drum loaded at $80 \mathrm{Ci}$, and 3 drums loaded at 8 $\mathrm{Ci}$, 2) 1 drum loaded at $1100 \mathrm{Ci}$, and 3) 4 drums loaded at $80 \mathrm{Ci}$. The source calculation of case 2 in this example has shown that although the drum loading is much higher than the base case, the dose is expected to be much lower. The counter-intuitive observation reflects the storage configuration for the standard 55-gallon drums containing more than $80 \mathrm{PE}-\mathrm{Ci}$. Large curiecontaining drums are overpacked into 85 -gallon drums for safer handling. The product of the damage ratio, airborne release fraction, and the respirable fraction shown in Eq. 10, therefore, will be orders of magnitude lower than a drum that is not overpacked. 
Comparisons of Table II and Figure 11 show that many of the dose calculations in the SAR are higher than the probabilistic dose at the $95 \%$ confidence level. Lower doses calculated in the probabilistic dose assessment are expected, since many of the input data are sampled from a relatively large range, hence a smearing of high and low values. However, higher doses seen in the probabilistic dose assessment are not expected, and may show where the deterministically determined doses may be underrepresenting the worst case conditions. For example, the probabilistic dose assessment assumes that all drums are loaded equally, and when a relatively large number of drums are involved in an accident, such as scenario $\mathrm{CH} 5$ (waste hoist accident 28 drums involved), a larger dose is expected. The justification for the drums of equal loading is from observations of recent operating procedures at WIPP. A shipment of TRUPACT IIs will typically transport drums from a single waste stream, with the drum loading of each waste stream being similar. Handling of drums between unloading of the TRUPACT IIs to placement underground is typically confined to single shipments. Therefore, it is recommended that the SAR's dose consequence calculations be updated to reflect a more realistic source term based on the PDFs presented in this report. This could be accomplished by summing the $95 \%$ worst case drum curie content from each generator site, normalized to its total contribution of curies according to Table VII.

Finally, although the two methods described above are different, they are not meant to be mutually exclusive, but as complementary techniques (ICRP 1993). The ICRP identified both methods for assuring an adequate level of safety has been achieved and that no major contributors to risk has been overlooked (ICRP 1993). With that, it is recommended that the WIPP SAR be updated to include a probabilistic dose assessment. The inclusion would add to the level of safety and give confidence that all possible ranges of expected conditions have been addressed. However, consistency between the results will have to be analyzed and assessed. 


\section{REFERENCES}

40 CFR Part 191. Environmental standards for the management and disposal of spent nuclear fuel, high-level and transuranic wastes. Title 40, Protection of the environment; Chapter I, Environmental Protection Agency; Code of Federal Regulations. Washington, DC: National Archives and Records Administration. July 1, 1999.

[ANSI-ANS] American National Standards Institute, American Nuclear Society. 1999. American National Standard for determining meteorological information at nuclear facilities: ANSI ANS-3.11-1999. (Draft). La Grange Park (IL): ANS.

Apostolakis G. 1978. Probability and risk assessment: The subjective viewpoint and some suggestions. Nuclear Safety 19: 305-315.

Channell, JK; Rogers, JC; Neill, RH. 1986 Jun. Adequacy of TRUPACT-I design for transporting contact-handled transuranic waste to WIPP. Albuquerque (NM): Environmental Evaluation Group. EEG-33.

Decisioneering, Inc. 1998. CRYSTAL BALL [computer program]. Version 4. Denver(CO): Decisioneering, Inc.

Greenfield, MA. 1990 Jan. Probabilities of a Catastrophic Waste Hoist Accident at the Waste Isolation Pilot Plant. Albuquerque (NM): Environmental Evaluation Group. EEG-44.

Greenfield, MA; Sargent, TA. 1995 Nov. An Analysis of the Annual Probability of Failure of the Waste Hoist Brake System at the Waste Isolation Pilot Plant (WIPP). Albuquerque (NM): Environmental Evaluation Group. EEG-59.

Greenfield, MA; Sargent, TA. 1998 Jan. Probability of Failure of the Waste Hoist Brake System at the Waste Isolation Pilot Plant (WIPP). Albuquerque (NM): Environmental Evaluation Group. EEG-65.

Greenfield, MA; Sargent, TA. 2000 May. Probability of Failure of the TRUDOCK Crane System at the Waste Isolation Pilot Plant (WIPP). Albuquerque (NM): Environmental Evaluation Group. EEG-74.

Hey BE. 1994 Dec. GXQ 4.0 Program user's guide. Rev 1A. Richland (WA): Westinghouse Hanford Company. WHC-SD-GN-SWD-30002, rev 1A.

[IAEA] International Atomic Energy Agency. 1980. Atmospheric dispersion in nuclear power plant siting. Vienna (Austria): IAEA; (Safety Guide: 50-SG-S3).

[ICRP] International Commission on Radiation Protection. 1974. Report of the Task Group on Reference Man. New York: Pergamon Press; (ICRP Publication 23). 
[ICRP] International Commission on Radiological Protection. 1993. Protection from potential exposure: a conceptual framework. New York: Pergamon Press; (ICRP Publication 64).

Mueller, CJ; Folga, SM; Roglans-Ribas, J; Nabelssi, B; Mishima, J. 1998 Jun. A structured methodology for waste management facility accident analysis. Nuclear Technology 122:306-17.

Rucker, DF. 2000 Aug. Air Dispersion Modeling at the Waste Isolation Pilot Plant. Albuquerque (NM): Environmental Evaluation Group. EEG-76 (in press).

[DOE] US Department of Energy. 1988 Jul. Internal dose conversion factors. Washington, DC: DOE. DOE/EH-0071.

[DOE] US Department of Energy. 1994 Dec. Airborne release fractions/rates and respirable fractions for nonreactor nuclear facilities: DOE-HDBK-3010-94. Washington, DC: DOE.

DOE] US Department of Energy. 1995 Dec. Waste Isolation Pilot Plant transuranic waste baseline inventory report (BIR). Revision 3. DOE/CAO-95-1121, rev 3.

[DOE] US Department of Energy, Carlsbad Area Office. 1996 Oct. Title 40 CFR Part 191 Compliance Certification Application for the Waste Isolation Pilot Plant. Final. 21 volumes. Carlsbad (NM): DOE. DOE/CAO-1996-2184.

[DOE] US Department of Energy, Carlsbad Area Office. 1999 Jan. WIPP safety analysis report. Rev 3. Carlsbad (NM): DOE. DOE/WIPP-95-2065, rev 3.

[EPA] US Environmental Protection Agency. 1987 (rev 1995). On-site meteorological program guidance for regulatory modeling applications. Research Triangle Park (NC): EPA. Office of Air Quality Planning and Standards. EPA-450/4-87 013.

[EPA] Environmental Protection Agency. 1993. Environmental Radiation Protection Standards for the Management and Disposal of Spent Nuclear Fuel, High-Level, and Transuranic Radioactive Wastes. 40 Code of Federal Regulations Part 191.

[EPA] Environmental Protection Agency. 1996 Feb. Criteria for the Certification and Recertification of the Waste Isolation Pilot Plant's Compliance with the 40 CFR 191 Disposal Regulations; Final Rule. Federal Register 61(28):5224-5245.

[EPA] US Environmental Protection Agency. 1998 May 18. Criteria for the certification and recertification of the Waste Isolation Pilot Plant's compliance with the 40 CFR part 191 disposal regulations: certification decision; final rule. Federal Register 63(95):27354-27406.

[NRC] US Nuclear Regulatory Commission. 1982 Nov. Atmospheric dispersion models for potential accident consequence assessments at nuclear power plants. Rev 1 . Washington DC: NRC; (NRC Regulatory Guide: 1.145). 
Vose D. 1996. Quantitative risk analysis: A guide to Monte Carlo simulation modeling. New York: John Wiley and Sons.

Westinghouse Electric Company, Waste Isolation Division. 1995 Apr. Hazard and operability study for CH-TRU waste handling system, Waste Isolation Pilot Plant, Carlsbad, NM. WCAP 14312.

Westinghouse Electric Company, Waste Isolation Division. 1997. WIPP Meteorological Quality Assurance Plan. Carlsbad (NM): Westinghouse. WP 02-EM.01. 


\subsection{LIST OF ACRONYMS}

$\begin{array}{ll}\text { ANS } & \text { American Nuclear Society } \\ \text { ANSI } & \text { American National Standard Institute } \\ \text { BR } & \text { Breathing Rate } \\ \text { CCA } & \text { Compliance Certification Application } \\ \text { CDF } & \text { Cumulative Distribution Function } \\ \text { CEDE } & \text { Cumulative Effective Dose Equivalent } \\ \text { CFR } & \text { Codi of Federal Regulations } \\ \text { CH } & \text { Contact Handled } \\ \text { CMR } & \text { Central Monitoring Room } \\ \text { DCF } & \text { Dose Conversion Factor } \\ \text { DOE } & \text { U.S. Department of Energy } \\ \text { EEG } & \text { Environmental Evaluation Group } \\ \text { EPA } & \text { U.S. Environmental Protection Agency } \\ \text { HEPA } & \text { High Efficiency Particulate } \\ \text { IAEA } & \text { International Atomic Energy Agency } \\ \text { ICRP } & \text { International Commission of Radiological Protection } \\ \text { LWB } & \text { Land Withdrawal Boundary } \\ \text { MEI } & \text { Maximally Exposed Individual } \\ \text { MSHA } & \text { Mining Safety and Health Administration } \\ \text { NCRP } & \text { National Council on Radiation Protection and Measurement } \\ \text { NESHAPS } & \text { National Emission Standards for Hazardous Air Pollutants } \\ \text { NRC } & \text { Nuclear Regulatory Commission } \\ \text { NRG } & \text { Nuclear Regulatory Guide } \\ \text { RCRA } & \text { Resource Conservation and Recovery Act } \\ \text { RH } & \text { Remote Handled } \\ \text { SAR } & \text { Safety Analysis Report } \\ \text { TRU } & \text { Transuranic Waste } \\ \text { WHB } & \text { Waste Handling Building } \\ \text { WIPP } & \text { Waste Isolation Pilot Plant } \\ & \end{array}$


LIST OF EEG REPORTS 


\section{LIST OF EEG REPORTS}

EEG-1 Goad, Donna, A Compilation of Site Selection Criteria Considerations and Concerns Appearing in the Literature on the Deep Disposal of Radioactive Wastes, June 1979.

EEG-2 Review Comments on Geological Characterization Report, Waste Isolation Pilot Plant (WIPP) Site, Southeastern New Mexico SAND 78-1596. Volume I and II, December 1978.

EEG-3 Neill, Robert H., James K. Channell, Carla Wofsy, Moses A. Greenfield (eds.) Radiological Health Review of the Draft Environmental Impact Statement (DOE/EIS-0026-D) Waste Isolation Pilot Plant. U.S. Department of Energy, August 1979.

EEG-4 Little, Marshall S., Review Comments on the Report of the Steering Committee on Waste Acceptance Criteria for the Waste Isolation Pilot Plant, February 1980.

EEG-5 Channell, James K., Calculated Radiation Doses From Deposition of Material Released in Hypothetical Transportation Accidents Involving WIPP-Related Radioactive Wastes, October 1980.

EEG-6 Geotechnical Considerations for Radiological Hazard Assessment of WIPP. A Report of a Meeting Held on January 17-18, 1980, April 1980.

EEG-7 Chaturvedi, Lokesh, WIPP Site and Vicinity Geological Field Trip. A Report of a Field Trip to the Proposed Waste Isolation Pilot Plant Project in Southeastem New Mexico, June 16 to 18, 1980, October 1980.

EEG-8 Wofsy, Carla, The Significance of Certain Rustler Aquifer Parameters for Predicting Long-Term Radiation Doses from WIPP, September 1980.

EEG-9 Spiegler, Peter, An Approach to Calculating Upper Bounds on Maximum Individual Doses From the Use of Contaminated Well Water Following a WIPP Repository Breach, September 1981.

EEG-10 Radiological Health Review of the Final Environmental Impact Statement (DOE/EIS-0026) Waste Isolation Pilot Plant, U. S. Department of Energy, January 1981.

EEG-11 Channell, James K., Calculated Radiation Doses From Radionuclides Brought to the Surface if Future Drilling Intercepts the WIPP Repository and Pressurized Brine, January 1982.

EEG-12 Little, Marshall S., Potential Release Scenario and Radiological Consequence Evaluation of Mineral Resources at WIPP, May 1982.

EEG-13 Spiegler, Peter, Analysis of the Potential Formation of a Breccia Chimney Beneath the WIPP Repository, May 1982.

EEG-14 Not published.

EEG-15 Bard, Stephen T., Estimated Radiation Doses Resulting if an Exploratory Borehole Penetrates a Pressurized Brine Reservoir Assumed to Exist Below the WIPP Repository Horizon - A Single Hole Scenario, March 1982.

EEG-16 Radionuclide Release, Transport and Consequence Modeling for WIPP. A Report of a Workshop Held on September 16-17, 1981, February 1982.

EEG-17 Spiegler, Peter, Hydrologic Analyses of Two Brine Encounters in the Vicinity of the Waste Isolation Pilot Plant (WIPP) Site, December 1982. 


\section{LIST OF EEG REPORTS (Continued)}

EEG-18 Spiegler, Peter and Dave Updegraff, Origin of the Brines Near WIPP from the Drill Holes ERDA-6 and WIPP-12 Based on Stable Isotope Concentration of Hydrogen and Oxygen, March 1983.

EEG-19 Channell, James K., Review Comments on Environmental Analysis Cost Reduction Proposals (WIPP/DOE-136) July 1982, November 1982.

EEG-20 Baca, Thomas E., An Evaluation of the Non-Radiological Environmental Problems Relating to the WIPP, February 1983.

EEG-21 Faith, Stuart, Peter Spiegler, Kenneth R. Rehfeldt, The Geochemistry of Two Pressurized Brines From the Castile Formation in the Vicinity of the Waste Isolation Pilot Plant (WIPP) Site, April 1983.

EEG-22 EEG Review Comments on the Geotechnical Reports Provided by DOE to EEG Under the Stipulated Agreement Through March 1, 1983, April 1983.

EEG-23 Neill, Robert H., James K. Channell, Lokesh Chaturvedi, Marshall S. Little, Kenneth Rehfeldt, Peter Spiegler, Evaluation of the Suitability of the WIPP Site, May 1983.

EEG-24 Neill, Robert H. and James K. Channell, Potential Problems From Shipment of High-Curie Content Contact-Handled Transuranic (CH-TRU) Waste to WIPP, August 1983.

EEG-25 Chaturvedi, Lokesh, Occurrence of Gases in the Salado Formation, March 1984.

EEG-26 Spiegler, Peter, Proposed Preoperational Environmental Monitoring Program for WIPP, November 1984.

EEG-27 Rehfeldt, Kenneth, Sensitivity Analysis of Solute Transport in Fractures and Determination of Anisotropy Within the Culebra Dolomite, September 1984.

EEG-28 Knowles, H. B., Radiation Shielding in the Hot Cell Facility at the Waste Isolation Pilot Plant: A Review, November 1984.

EEG-29 Little, Marshall S., Evaluation of the Safety Analysis Report for the Waste Isolation Pilot Plant Project, May 1985.

EEG-30 Dougherty, Frank, Tenera Corporation, Evaluation of the Waste Isolation Pilot Plant Classification of Systems, Structures and Components, July 1985.

EEG-31 Ramey, Dan, Chemistry of the Rustler Fluids, July 1985.

EEG-32 Chaturvedi, Lokesh and James K. Channell, The Rustler Formation as a Transport Medium for Contaminated Groundwater, December 1985.

EEG-33 Channell, James K., John C. Rodgers, Robert H. Neill, Adequacy of TRUPACT-I Design for Transporting Contact-Handled Transuranic Wastes to WIPP, June 1986.

EEG-34 Chaturvedi, Lokesh, (ed.), The Rustler Formation at the WIPP Site, Report of a Workshop on the Geology and Hydrology of the Rustler Formation as it Relates to the WIPP Project, February 1987.

EEG-35 Chapman, Jenny B., Stable Isotopes in Southeastern New Mexico Groundwater: Implications for Dating Recharge in the WIPP Area, October 1986. 


\section{LIST OF EEG REPORTS (Continued)}

EEG-36 Lowenstein, Tim K., Post Burial Alteration of the Permian Rustler Formation Evaporites, WIPP Site, New Mexico, April 1987.

EEG-37 Rodgers, John C., Exhaust Stack Monitoring Issues at the Waste Isolation Pilot Plant, November 1987.

EEG-38 Rodgers, John C. and Jim W. Kenney, A Critical Assessment of Continuous Air Monitoring Systems at the Waste Isolation Pilot Plant, March 1988.

EEG-39 Chapman, Jenny B., Chemical and Radiochemical Characteristics of Groundwater in the Culebra Dolomite. Southeastern New Mexico, March 1988.

EEG-40 Review of the Final Safety Analyses Report (Draft), DOE Waste Isolation Pilot Plant. December 1988, May 1989.

EEG-41 Review of the Draft Supplement Environmental Impact Statement, DOE Waste Isolation Pilot Plant, July 1989.

EEG-42 Chaturvedi, Lokesh, Evaluation of the DOE Plans for Radioactive Experiments and Operational Demonstration at WIPP, September 1989.

EEG-43 Kenney, Jim W., John Rodgers, Jenny Chapman, Kevin Shenk, Preoperational Radiation Surveillance of the WIPP Project by EEG 1985-1988, January 1990.

EEG-44 Greenfield, Moses A., Probabilities of a Catastrophic Waste Hoist Accident at the Waste Isolation Pilot Plant, January 1990.

EEG-45 Silva, Matthew K., Preliminary Investigation into the Explosion Potential of Volatile Organic Compounds in WIPP CH-TRU Waste, June 1990.

EEG-46 Gallegos, Anthony F. and James K. Channell, Risk Analysis of the Transport of Contact Handled Transuranic (CH-TRU) Wastes to WIPP Along Selected Highway Routes in New Mexico Using RADTRAN IV, August 1990.

EEG-47 Kenney, Jim W. and Sally C. Ballard, Preoperational Radiation Surveillance of the WIPP Project by EEG During 1989, December 1990.

EEG-48 Silva, Matthew, An Assessment of the Flammability and Explosion Potential of Transuranic Waste, June 1991.

EEG-49 Kenney, Jim, Preoperational Radiation Surveillance of the WIPP Project by EEG During 1990, November 1991.

EEG-50 Silva, Matthew K. and James K. Channell, Implications of Oil and Gas Leases at the WIPP on Compliance with EPA TRU Waste Disposal Standards, June 1992.

EEG-51 Kenney, Jim W., Preoperational Radiation Surveillance of the WIPP Project by EEG During 1991, October 1992.

EEG-52 Bartlett, William T., An Evaluation of Air Effluent and Workplace Radioactivity Monitoring at the Waste Isolation Pilot Plant, February 1993.

EEG-53 Greenfield, Moses A. and Thomas J. Sargent, A Probabilistic Analysis of a Catastrophic Transuranic Waste Hoist Accident at the WIPP, June 1993. 


\section{LIST OF EEG REPORTS (Continued)}

EEG-54 Kenney, Jim W., Preoperational Radiation Surveillance of the WIPP Project by EEG During 1992, February 1994.

EEG-55 Silva, Matthew K., Implications of the Presence of Petroleum Resources on the Integrity of the WIPP, June 1994.

EEG-56 Silva, Matthew K. and Robert H. Neill, Unresolved Issues for the Disposal of Remote-Handled Transuranic Waste in the Waste isolation Pilot Plant, September 1994.

EEG-57 Lee, William W.-L, Lokesh Chaturvedi, Matthew K. Silva, Ruth Weiner, and Robert H. Neill, An Appraisal of the 1992 Preliminary Performance Assessment for the Waste Isolation Pilot Plant, September 1994.

EEG-58 Kenney, Jim W., Paula S. Downes, Donald H. Gray, Sally C. Ballard, Radionuclide Baseline in Soil Near Project Gnome and the Waste Isolation Pilot Plant, June 1995.

EEG-59 Greenfield, Moses A. and Thomas J. Sargent, An Analysis of the Annual Probability of Failure of the Waste Hoist Brake System at the Waste Isolation Pilot Plant (WIPP), November 1995.

EEG-60 Bartlett, William T. and Ben A. Walker, The Influence of Salt Aerosol on Alpha Radiation Detection by WIPP Continuous Air Monitors, January 1996.

EEG-61 Neill, Robert, Lokesh Chaturvedi, William W.-L. Lee, Thomas M. Clemo, Matthew K. Silva, Jim W. Kenney, William T. Bartlett, and Ben A. Walker, Review of the WIPP Draft Application to Show Compliance with EPA Transuranic Waste Disposal Standards, March 1996.

EEG-62 Silva, Matthew K., Fluid Injection for Salt Water Disposal and Enhanced Oil Recovery as a Potential Problem for the WIPP: Proceedings of a June 1995 Workshop and Analysis, August 1996.

EEG-63 Maleki, Hamid and Lokesh Chaturvedi, Stability Evaluation of the Panel 1 Rooms and the E140 Drift at WIPP, August 1996.

EEG-64 Neill, Robert H., James K. Channell, Peter Spiegler, Lokesh Chaturvedi, Review of the Draft Supplement to the WIPP Environmental Impact Statement, DOE/EIS-0026-S-2, April 1997.

EEG-65 Greenfield, Moses A. and Thomas J. Sargent, Probability of Failure of the Waste Hoist Brake System at the Waste Isolation Pilot Plant (WIPP), January 1998.

EEG-66 Channell, James K. and Robert H. Neill, Individual Radiation Doses From Transuranic Waste Brought to the Surface by Human Intrusion at the WIPP, February 1998.

EEG-67 Kenney, Jim W., Donald H. Gray, and Sally C. Ballard, Preoperational Radiation Surveillance of the WIPP Project by EEG During 1993 Though 1995, March 1998.

EEG-68 Neill, Robert H., Lokesh Chaturvedi, Dale F. Rucker, Matthew K. Silva, Ben A. Walker, James K. Channell, Thomas M. Clemo, Evaluation of the WIPP Project's Compliance with the EPA Radiation Protection Standards for Disposal of Transuranic Waste, March 1998.

EEG-69 Rucker, Dale, Sensitivity Analysis of Performance Parameters Used In Modeling the Waste Isolation Pilot Plant, May 1998.

EEG-70 Bartlett, William T. and Jim W. Kenney, EEG Observations of the March 1998 WIPP Operational Readiness Review Audit, May 1998. 


\section{LIST OF EEG REPORTS (Continued)}

EEG-71 Maleki, Hamid, Mine Stability Evaluation of Panel 1 During Waste Emplacement Operations at WIPP, July 1998.

EEG-72 Channell, James K. and Robert H. Neill, A Comparison of the Risks from the Hazardous Waste and Radioactive Waste Portions of the WIPP Inventory, July 1999.

EEG-73 Kenney, Jim W., Donald H. Gray, Sally C. Ballard, and Lokesh Chaturvedi, Preoperational Radiation Surveillance of the WIPP Project by EEG from 1996 - 1998, October 1999.

EEG-74 Greenfield, Moses A. and Thomas J. Sargent, Probability of Failure of the TRUDOCK Crane System at the Waste Isolation Pilot Plant (WIPP), May 2000.

EEG-75 Channell, James K. and Ben A. Walker, Evaluation of Risks and Waste Characterization Requirements for the Transuranic Waste Emplaced in WIPP During 1999, May 2000.

EEG-76 Rucker, Dale F., Air Dispersion Modeling at the Waste Isolation Pilot Plant, August 2000.

EEG-77 Oversby, Virginia M., Plutonium Chemistry Under Conditions Relevant for WIPP Performance Assessment, September 2000.

EEG-78 Rucker, Dale F., Probabilistic Safety Assessment of Operational Accidents at the Waste Isolation Pilot Plant, September 2000. 